\title{
Discovery of the largest lungless tetrapod, Atretochoana eiselti (Taylor, 1968) (Amphibia: Gymnophiona: Typhlonectidae), in its natural habitat in Brazilian Amazonia

\author{
Descoberta do maior Tetrapoda apulmonado, Atretochoana eiselti \\ (Taylor, 1968) (Amphibia: Gymnophiona: Typhlonectidae), \\ em seu habitat natural na Amazônia brasileira
}

\author{
Marinus Steven Hoogmoed", Adriano Oliveira Maciel', Juliano Tupan Coragem" \\ IMuseu Paraense Emílio Goeldi. Coordenação de Zoologia. Belém, Pará, Brasil \\ "Santo Antônio Energia S.A. Porto Velho, Rondônia, Brasil
}

\begin{abstract}
We report the occurrence of the limbless and lungless tetrapod, Atretochoana eiselti, in two widely separated Brazilian Amazonian lowland localities, one (Mosqueiro island and Baía de Marajó, Belém) near the mouth of the Amazon river and another (Cachoeira Santo Antônio) near the border between Brazil and Bolivia in the Madeira river. It is shown that this species is not an inhabitant of cool, oxygen rich and fast running water in elevated localities as supposed until now, but on the contrary occurs in warm $\left(24-30^{\circ} \mathrm{C}\right)$, turbid, fast running water in the lowland Brazilian Amazon basin. We describe the probable habitat and three freshly preserved specimens (one male, two females) and compare them to the only two specimens known; some data are provided about the biology of this species, that seems to have a wide distribution in Brazilian Amazonia and possibly also occurs in other countries, like Bolivia.
\end{abstract}

Keywords: Atretochoana eiselti. Gymnophiona. Lungless vertebrate. Amazon Basin. Brazil.

Resumo: Registra-se a ocorrência do maior Tetrapoda ápode e apulmonado, Atretochoana eiselti, em duas localidades na bacia amazônica brasileira, amplamente separados entre si e ambos a baixas altitudes: um próximo à foz do rio Amazonas (ilha de Mosqueiro e baía de Marajó, Belém, Pará) e o outro no rio Madeira (Cachoeira Santo Antônio, Rondônia), próximo à fronteira entre Brasil e Bolívia. Fica claro que essa espécie não habita águas frias, em ambiente de correnteza saturado de oxigênio, a grandes altitudes, como se supunha até agora, mas, ao contrário, habita águas quentes com temperaturas em torno de $24-30^{\circ} \mathrm{C}$, turvas, com correnteza, nas terras baixas da bacia amazônica brasileira. Descreve-se o habitat provável da espécie e três novos exemplares (um macho, duas fêmeas) recém-coletados, comparando-os com os dois exemplares já conhecidos, e apresentam-se alguns dados sobre a biologia dessa espécie, que parece ter distribuição ampla na Amazônia brasileira e possivelmente pode ocorrer em outros paises, como a Bolívia.

Palavras-chave: Atretochoana eiselti. Gymnophiona. Vertebrado apulmonado. Bacia amazônica. Brasil.

HOOGMOED, M. S., A. O. MACIEL \&J. T. CORAGEM, 2011. Discovery of the largest lungless tetrapod, Atretochoana eiselti (Taylor, 1968) (Amphibia: Gymnophiona: Typhlonectidae), in its natural habitat in Brazilian Amazonia. Boletim do Museu Paraense Emílio Goeldi. Ciências Naturais 6(3): 241-262.

Autor para correspondência: Marinus Steven Hoogmoed. Museu Paraense Emílio Goeldi. Coordenação de Zoologia. Av. Perimetral, 1901 - Terra Firme. Belém, PA, Brasil. CEP $66017-970$ (marinus@museu-goeldi.br).

Recebido em 22/11/2011

Aprovado em 09/01/2012

Responsabilidade editorial: Hilton Tulio Costi

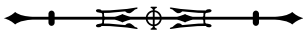




\section{INTRODUCTION}

The lungless Gymnophiona Atretochoana eiselti was described by Taylor (1968) as Typhlonectes eiselti on the basis of one old specimen in the Vienna Museum (NMW) from South America without further details. The fact that the specimen was lungless, at the time of its description was not noticed. Since its description the species was only sparingly mentioned in the literature (Frost, 1985; Duellman \& Trueb, 1986), until Nussbaum \& Wilkinson (1995) studied the type specimen in great detail and discovered it was lungless and merited to be placed in its own genus, Atretochoana. Wilkinson \& Nussbaum (1997) made extensive, exemplary, and detailed anatomical and morphological studies of the type specimen that produced a wealth of knowledge about the external morphology, the skeleton, myology, and circulatory system of this strange caecilian, but it was not possible to relate these characters to the way of life of $A$. eiselti because nothing was known about that, except that the species most likely was aquatic. Wilkinson \& Nussbaum (1997) did speculate that its large size and its reliance on cutaneous respiration "implied an upland environment in cold fast moving waters" for this species. Wilkinson et al. (1998) discovered a second specimen of this lungless caecilian (without data) in the collection of the University of Brasilia, Brazil (CHUNB), which was even longer than the type specimen (respectively $805 \mathrm{~mm}$ and $738 \mathrm{~mm}$ ). These authors provided morphometric and meristic data of this second specimen, and thus were able to prudently discuss individual variation. Based on the fact that the University of Brasilia collection is relatively young (the university was only established in 1961) and only contains few specimens from countries other than Brazil, the authors hypothesized that the specimen probably was collected in Brazil after or not much before 1961, but there was no hard evidence to support their suggestion. Wilkinson \& Nussbaum (1999) studied the evolutionary relationships of $A$. eiselti and other Typhlonectidae and came to the conclusion that Potomotyphlus was the sister group of Atretochoana. Wilkinson et al. (2011) listed the genus Atretochoana in their family Typhlonectidae. The species was further mentioned in several textbooks which did not add new information (Pough et al., 1998; Hofrichter, 1998; Zug et al., 2001; Wilkinson \& Nussbaum, 2006; Exbrayat \& Estabel, 2006; Wells, 2007; Vitt \& Caldwell, 2009). Frost (2011) apparently is not aware of the fact that in 1998 a second specimen of $A$. eiselti was discovered and described by Wilkinson et al. (1998) as he only refers to the type specimen in the Vienna Museum with unknown locality in South America, possibly Brazil.

Maciel \& Hoogmoed (2011), in a paper dealing with the caecilians of Brazilian Amazonia, suggested that this species possibly could occur in Brazilian Amazonia, although there was no hard evidence at that time.

Wake \& Donnelly (2009) described a second species of lungless gymnophiona, Caecilita iwokramae from Guyana. This species is radically different from A. eiselti: it belongs to the terrestrial family Siphonopidae, lacks open external nostrils, and it is very small (total length $112 \mathrm{~mm}$ ).

\section{MATERIALS AND METHODS}

After we received evidence of the presence of $A$. eiselti near the island of Mosqueiro, just north of Belém, we contacted several shrimp fishers in the area. As a result we received two freshly caught specimens preserved in alcohol 70\%. The first (released) specimen from Mosqueiro island was collected in a 'matapi' (= cylindrical shrimp trap of wooden slats, with funnel-shaped entrances at both sides), the other two specimens that were preserved, were collected in large meshed vertical gill nets in the channel in the middle of the Baía de Marajó. The specimens reported from Rondônia were collected with cast nets in a pool remaining after upstream closure of a channel at the site of the future hydroelectric plant Santo Antônio in the Madeira river. All specimens destined to the Museu Paraense Emílio Goeldi (MPEG) collection were directly preserved in alcohol $70 \%$, so tissues are suitable for DNA studies. We have now developed a program (both at Mosqueiro island and in the Madeira river area) to try to obtain more specimens of this interesting caecilian in order to be able to study its 
relationships, more aspects of its functional anatomy, of its natural history and possibly of its physiology.

Specimens were measured following Wilkinson et al. (1998), but some additional characters were observed. Measures were taken with an electronic caliper to the nearest $0.1 \mathrm{~mm}$, except TL and the circumference of the body that were measured with a tape measure to the nearest $\mathrm{mm}$. We have preferred not to try to give a number for primary body annuli. Because of the wrinkles on the body this count is very unreliable, as also indicated by Wilkinson et al. (1998), who nevertheless proceeded giving numbers. In one of our specimens we were unable to count primary annuli at all because of numerous wrinkles in the skin, in two specimens we could count primary annuli, but the number we arrived at is not the exact number of primary annuli because in the anterior part of the body there are irregularities in grooves that did not allow a good count. We have considered vertebrae posterior to the posterior end of the cloacal disk as postcloacal vertebrae. Unfortunately it is not clear how Wilkinson \& Nussbaum (1997) and Wilkinson et al. (1998) exactly counted postcloacal vertebrae, but probably they used the cloacal opening as their starting point, which explains the differences in number noted here. Vertebrae were counted using X-ray photos made in a veterinary clinic in Belém.

We made several measurements of the head that were not clearly defined by Wilkinson et al. (1998). Their "head length" probably refers to the distance between the tip of the snout and the first gular groove, as this measure is normally taken in Gymnophiona. As we could not reliably discern gular grooves we used a different measurement, defined as follows. Our 'head length MPEG' is the straight line distance between the tip of the snout and the line that connects the posterior ends of both mandibulae. Cranium length is the distance between the tip of the snout and the articulation between skull and first vertebra (thus, it is shorter than 'head length MPEG'). Mandibular length is the distance between the anterior point of the lower jaw and the posterior end of one mandibula, measured along the bone.

\section{RESULTS}

On June 29, 2011, Marina Barreira Mendonça, of Belém (PA), sent to $\mathrm{MSH}$ and AOM eight pictures of a large typhlonectid that had been captured on June 4 in a shrimp trap baited with chicken meat and set in shallow water in front of Praia de Marahú on Mosqueiro island (01 04.500' S - 48² 24.722' W / UTM 22M 787550; 9880177; Figure $1 \mathrm{~A}, \mathrm{C}, \mathrm{D})$, north of Belém, Pará, Brazil, at sea level. The matapi was placed at high tide in an area where rocky formations and sand alternate (Figure 1C) at about 8:00 h and it was removed again at low tide at about 15:00 h. The matapi contained the typhlonectid and shrimps. Unfortunately the specimen (Figure 1B), which measured about $105 \mathrm{~cm}$ (based on measurement of the tiles it had been photographed on), was released after pictures had been taken. Study of the pictures showed that the animal had a large flat head with large terminal nostrils. Our initial identification was that this was a specimen of Atretochoana eiselti, and thus it would constitute the first specimen with a known locality for the species that until that moment was only known from two preserved specimens without detailed locality data (Wilkinson et al., 1998). Unfortunately we could not prove our conclusion with a voucher specimen. Another specimen, possibly of this same species, was observed on June 5 by Mr. Mendonça (Marina's father), swimming at the surface near a small off-shore island in front of Praia de Marahú in daytime, but when approached by the boat it dived deeper.

On August 8, 2011, the senior author was contacted by the junior author JTC who sent him some very good pictures of a large caecilian that had been collected on August 1, 2011 in the bed of the Madeira river, in Cachoeira Santo Antônio (Figure 2A), in a pool at an altitude of $4 \mathrm{~m}$ below sea level, at the construction site of a hydroelectric project, in an area of the river bed at the left bank of the Madeira river that had been closed off upstream on July 30, 2011 and was drying out (Figure 2C, D). The land along the Madeira river at the site has an elevation of about $50 \mathrm{~m}$ above sea level. From the 
pictures received it was immediately clear that this was a specimen of $A$. eiselti, that agreed very much with the published pictures of the holotype and the second known specimen. This specimen fortunately was collected and directly preserved in alcohol 70\% (no formalin fixation), and we have initiated molecular studies of tissue samples to evaluate the relationships of this species with other typhlonectids. The specimen has been deposited in the herpetological collection of the Museu Paraense Emílio Goeldi, Belém, Pará, Brazil (MPEG 33292). On August 4, 2011, three additional, smaller specimens (estimated to be 30-40 cm total length) were collected at the same spot as the first specimen. One of these individuals was extensively photographed (Figures 2B and 3D) and the three specimens were released again in the Madeira river.

As a result of our contacts with fishermen in Mosqueiro island, on November 8, 2011, we obtained two specimens (male and female) of $A$. eiselti collected in the Baía de Marajó on different days, and which were also deposited in the collection of the Museu Paraense Emílio Goeldi (MPEG 33578, 33579).

We here provide a description of the recently collected fresh specimens, including a comparison with the other two known specimens, data on the probable habitat of $A$. eiselti, and a discussion about our present knowledge.

\section{DESCRIPTION OF MPEG 33292, 33578, 33579} 1 , , MPEG 33292 (fieldnumber CAN-A2501), Canteiro de obras/UHE Santo Antônio, subarea LR1-LR1' (ensecadeira leito do rio Madeira-MD) 08 48' 03.22" S, 63 57' 13,81" W/UTMX395157, UTMY 9027066), 1-VIII-2011, 10:00 $\mathrm{h}$, leg. Equipe de resgate de peixes (= Fish rescue team). 1 o', MPEG 33578, Baía de Marajó, 00 59' 33" S, $48^{\circ}$ 26' 37" W / UTM 22M 784515, 9890188.; 8-X-2011, leg. Local fishermen. 1 \&, MPEG 33579, same locality and collectors as MPEG 33578; 4-XI-2011.

Diagnosis: A large aquatic caecilian of the family Typhlonectidae that can be distinguished from all other caecilians in the Amazon basin mainly by its size (up to more than $100 \mathrm{~cm}$ ), by its large, broad, flat head with strongly protruding bulbous snout, eyes in depressions, the presence of large external nostrils directed anteriorly, by having the choanae sealed completely, by the absence of lungs, by having a very high number of teeth, and by having 11-13 vent denticles.

Description: MPEG 33292 is an adult female with a total length of $1,000 \mathrm{~mm}$ and a weight of $570 \mathrm{~g}$ (after two months in alcohol 70\%) (Figures 3A, 3B, 4A, 4B, 5, 6). This is a thick-set specimen with a loose, baggy skin. Total length 37 times body width. Head broad, distinctly flattened, subtriangular in dorsal view. Posterior part of head widened laterally, because of the posteriorly extending mandibulae which form two bulbous areas making the posterior end of the head distinctly wider than the adjacent part of the body. Margin of the upper jaw curving downwards, with the highest point of the concavity formed anteriorly to the eyes, closer to the eyes than to the tentacles. Snout bulbous, projecting $9.4 \mathrm{~mm}$ beyond the anterior margin of the mouth. Tip of snout rounded in dorsal and lateral views. Eyes visible in lateral and dorsal view of the head, in a marked depression on the dorsal surface of the head, slightly above the level of the tentacles and nostrils. Opening of tentacles in a small sub-circular slit, smaller than $1 \mathrm{~mm}$ in diameter, slightly under the inferior border of the nostrils, closer to nostrils than to eyes. Nostrils large (diameter of the aperture $2.1 \mathrm{~mm}$ ), in a distinct depression, which is visible on the dorsal side of head. Skin of dorsal surface of head and that covering the mandibles seems to be grown together with underlying bones.

Nuchal grooves indistinct. Few incomplete annular body grooves distinct, very difficult to locate because of the wrinkled condition of the skin. Lateral and ventral surfaces of body strongly marked by irregular wrinkles that seem to be arranged in groups. Dorsal region of body with considerably fewer of these wrinkles in the region where a distinct dorsal fin is present, from near head to tip of terminal region of body. Because of the condition of the skin we could not make reliable counts 
of primary annuli. Numerous mucous glands in the skin visible as rounded spots.

A distinct fleshy extension beyond the vent $(11 \mathrm{~mm}$ from the posterior border of the vent to the posterior tip of the body), containing two post-cloacal vertebrae. In total there are 114 vertebrae. Thirteen denticulations around the vent, two of which are partially fused. Cloacal disk slightly extended anteriorly, drop-shaped (point directed anteriorly); three anterior denticulations are slightly elongated (Figure 6).

Tongue completely attached to the mandibular mucosa, having a medially anterior extension to the tip of the lower lip. Numerous monocuspid teeth (Table 1). Dentary and splenial (inner mandibular) teeth posteriorly extending to the level of the corner of the mouth. Premaxillary-maxillary and vomeropalatine series extending beyond posterior level of choanae, but not reaching the level of the corner of mouth. Choanae sealed by the choanal valves that measure 9.4 (length) $\times 5 \mathrm{~mm}$ (width). An indistinct, very shallow longitudinal furrow from the tip of the tongue extending posteriorly. Indistinct oval areas on both sides of the groove are complementary to the choanal seals.

Some details about internal morphology (Figure 7): The liver starts at $190 \mathrm{~mm}$ from the tip of the snout and has a length of $400 \mathrm{~mm}$. The large, very wide posterior vena cava is present above the liver in its anterior part. There are no developed ova in the ovary and no fetuses in the uterus. The ovaries start at $500 \mathrm{~mm}$ from the tip of the snout and are $320 \mathrm{~mm}$ long. The urinary bladder is elongated (as all other organs), having two lobes, an anterior $(38.2 \mathrm{~mm}$ ) and a posterior one $(7 \mathrm{~mm})$, making a total length of $45.2 \mathrm{~mm}$; it is totally attached to the body wall by mesenteric tissue. Its posterior lobe ends $30 \mathrm{~mm}$ before the vent.

MPEG 33579, also a thick-set female (Figures 8, 9), agrees in most essential characters with MPEG 33292, but has different meristics and measurements, which are compiled in Table 1. Due to preservation, the cloacal disk of this specimen is surrounded by folds of skin (Figure 10), but these are completely different from the continuous ridge that is present around the cloacal disk of the male MPEG 33578. On the median dorsal surface of the anterior part of the head there is a small flat bulbous area, which might just be an individual variation. The tongue shows a distinct, deep furrow from the tip running posteriorly. Oval areas on both sides of the furrow near the tip of the tongue are slightly elevated and are complementary to the choanal seals. We hesitate to call these narial plugs as Nussbaum \& Wilkinson (1995) do. The number of cloacal denticulations is a bit different than in all other specimens. There are eight distinct denticulations and a large area that shows two partial divisions and which could be considered as three partially joined denticulations, making up a total of 11 denticulations. In this specimen we counted 110 primary annuli to the anterior border of the cloacal disc and possibly three annuli at the side of the vent, but in the area directly behind the head reliable counts were not possible because there are numerous incomplete grooves there.

MPEG 33578, is a male, whose meristics and measurements are presented in Table 1. It differs from the female specimens by the structure of its cloacal disk, by the shape of its head (oval, not triangular), and by its much thinner and elongate body (Figures 8, 9, 10 and Table 1). The tongue is as in MPEG 33579. The cloacal disk is slightly sunk into the body surface and is completely surrounded by a continuous, overhanging fleshy ridge of $1.6 \mathrm{~mm}$ high (Figure 10), neatly separating it from the surrounding area. The entire area gives the impression of a cup-shaped suction disk. Taylor (1968) assumed that this differentiated cloacal disk in typhlonectids might play a role during copulation by anchoring the male to the female, but Duellman \& Trueb (1986) and Himstedt (1996) reported that in none of the copulations described for typhlonectids this was the case. The males were just attached to the females by the inserted phallodeum. 
Table 1. Measurements in mm and counts of the known preserved specimens of Atretochoana eiselti (Taylor, 1968), based on data in Wilkinson et al. (1998) and new material in MPEG. Question-marks mean that the data were not given in Wilkinson et al. (1998).

(Continued)

\begin{tabular}{|c|c|c|c|c|c|}
\hline & $\begin{array}{l}\text { MPEG } 33292 \\
\text { Rondônia }\end{array}$ & $\begin{array}{l}\text { MPEG } 33579 \\
\text { Mosqueiro }\end{array}$ & $\begin{array}{l}\text { MPEG } 33578 \\
\text { Mosqueiro }\end{array}$ & $\begin{array}{c}\text { Holotype } \\
\text { NMW } 9144 \\
\text { South America }\end{array}$ & $\begin{array}{c}\text { CHUNB } 1754 \\
---\end{array}$ \\
\hline Sex & 우 & 운 & $\hat{\sigma}$ & 웅 & q \\
\hline Total length & 1000 & 950 & 720 & 738 & 805 \\
\hline Weight & 570 & 840 & 140 & $?$ & $?$ \\
\hline Head length & $?$ & $?$ & $?$ & 28.2 & 27.1 \\
\hline Head length MPEG & 46.4 & 37.7 & 27.2 & $?$ & $?$ \\
\hline Length cranium & 32.5 & 27.5 & 23.3 & $?$ & $?$ \\
\hline Head width at jaw articulation & 31 & 29 & 18.9 & 23.3 & 21.1 \\
\hline $\begin{array}{l}\text { Head height at corner } \\
\text { of the mouth }\end{array}$ & 16 & 14.8 & 9 & 12 & 10.2 \\
\hline Lower jaw length & 30.6 & 31 & 18 & 19 & 18.5 \\
\hline Snout projection beyond mouth & 9.4 & 7.5 & 5.6 & 6.2 & 5.5 \\
\hline Snout tip to eye level & 19.5 & 16.8 & 10 & 11.2 & 11.6 \\
\hline Eye-eye distance & 20.4 & 16.8 & 8.2 & 12.7 & 13.4 \\
\hline Eye-tentacle & 9.7 & 7.6 & 5.7 & 6.2 & 7.4 \\
\hline Eye-naris distance & 11.8 & 11.2 & 7.5 & 8.6 & 9 \\
\hline Eye diameter & 1.8 & 1.5 & 1.4 & $?$ & $?$ \\
\hline Internarial distance & 12.5 & 9.8 & 8.2 & 8.5 & 8.5 \\
\hline Naris to margin of mouth distance & 6.1 & 4.8 & 3.7 & $?$ & $?$ \\
\hline Intertentacular distance & 21 & 17.3 & 11.5 & $?$ & $?$ \\
\hline Tentacle to naris distance & 3.5 & 3.3 & 1.9 & 2.5 & 2.7 \\
\hline $\begin{array}{l}\text { Tentacle to corner of } \\
\text { mouth distance }\end{array}$ & 26.4 & 23.9 & 16.3 & $?$ & $?$ \\
\hline $\begin{array}{l}\text { Tentacle to margin of } \\
\text { mouth distance }\end{array}$ & 3.9 & 3,7 & 2.8 & $?$ & $?$ \\
\hline Height at mid-body & 37.3 & 45 & 18.7 & 28 & 16.1 \\
\hline Width at mid-body & 27 & 41.9 & 17.7 & 24.5 & 15.3 \\
\hline Circumference at mid-body & 107 & 136 & 59 & 90 & 53 \\
\hline Fin height at mid-body & 3.4 & 6.8 & 2.8 & 3.7 & 1.1 \\
\hline Length of cloacal disk & 15 & 14.9 & 17 & 11.1 & 12 \\
\hline Width of cloacal disk & 6.4 & 10.2 & 8.4 & 6.6 & 6.1 \\
\hline Vent denticulations & 13 & 11 & 12 & 12 & 12 \\
\hline Anal papillae & present & present & present & $?$ & present \\
\hline $\begin{array}{l}\text { Distance of vent from posterior } \\
\text { edge of cloacal disk }\end{array}$ & 5.6 & 6 & 6.4 & 4.3 & 3.6 \\
\hline
\end{tabular}


Table 1.

\begin{tabular}{|c|c|c|c|c|c|}
\hline & $\begin{array}{c}\text { MPEG } 33292 \\
\text { Rondônia }\end{array}$ & $\begin{array}{c}\text { MPEG } 33579 \\
\text { Mosqueiro }\end{array}$ & $\begin{array}{c}\text { MPEG } 33578 \\
\text { Mosqueiro }\end{array}$ & $\begin{array}{c}\text { Holotype } \\
\text { NMW } 9144 \\
\text { South America }\end{array}$ & CHUNB 1754 \\
\hline $\begin{array}{l}\text { Distance of vent to posterior } \\
\text { tip of the body }\end{array}$ & 11.6 & 16.6 & 10.3 & 12.3 & 9.5 \\
\hline Circumference at the vent level & 60 & 59 & 47.2 & 58 & 30 \\
\hline Fin height at the vent level & 3.8 & 4.2 & 5.3 & 9.8 & 3.1 \\
\hline Width at the vent level & 13.6 & 14.7 & 13 & 8.9 & 6.9 \\
\hline Height at the vent level & 22.2 & 22.3 & 14.9 & 16.6 & 10.3 \\
\hline Total length/Width at mid-body & 37 & 22.6 & 40.6 & 30.1 & 52.6 \\
\hline Primary annuli & $?$ & $\sim 107$ & $\sim 110$ & 102 & 100 \\
\hline Vertebrae & 114 & 116 & 115 & 118 & 115 \\
\hline Post-cloacal vertebrae & 2 & 2 & 2 & 5 & 5 \\
\hline Nuchal vertebrae & $?$ & $?$ & $?$ & 5 & 5 or 6 \\
\hline Choanal valves length $\times$ width & $9.4 \times 5$ & $8 \times 3.6$ & $5.8 \times 3$ & $?$ & $?$ \\
\hline Premaxillary-maxillary teeth & 53 & 42 & 41 & 54 & 51 \\
\hline Vomeropalatine teeth & 38 & 34 & 27 & 39 & 40 \\
\hline Dentary teeth & 54 & 40 & 38 & 45 & 51 \\
\hline Splenial teeth & 39 & 32 & 26 & 37 & 37 \\
\hline
\end{tabular}

The tip of the body extending beyond the cloacal disk is shorter than in females and not as pointed. We interprete the size difference between the only known male and the females as sexual dimorphism, as ontogenetic growth does not seem able to make up for the differences in size and shape seen between the adult male and only slightly longer adult females. We counted 107 primary annuli anteriorly of the anterior border of the cloacal disc and possibly five annuli at the side of the vent. Again, before the first distinct annulus there are a number of incomplete and not countable grooves.

Colour in preservative: Body grey, from middle of flank down onto the belly, lighter grey. Cloacal disk dirty white. Snout and frontal area of head, underside of snout, maxillar region, and mandibular region, purplish brown. Throat and gular region, dirty white. Eyes visible as pale grey areas. MPEG 33579 generally is coloured as the other two specimens, but throat, gular region, and venter with a reddish hue. Eyes visible as pink areas.
Colour in life (based on slides): Only available for the Madeira river specimens. Top of head and back brownish grey to blueish grey. Ventral parts only slightly lighter. Lower lips same colour as back. Throat dirty white, much lighter than lower lips. Cloacal disk pinkish in centre, surrounded by a grayish white area.

Individual variation: A comparison of measurements and meristic characters of the five known preserved specimens of Atretochoana eiselti is given in Table 1. MPEG 33292 and MPEG 33579 are larger than the other two known female specimens (NMW 9144, CHUNB AS1754) and different from them in not showing distinct nuchal and primary annular grooves, but that can be due to a different interpretation of distinctness by Wilkinson et al. (1998) and us. MPEG 33292, 33578, and 33579 differ in having smaller numbers of post-cloacal vertebrae than NMW 9144 and CHUNB AS1754, but the differences are well within possible intraspecific variation (Table 1). The number of teeth in the four series in the MPEG specimens

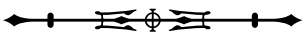


is approximately the same as in NMW 9144 and CHUNB AS1754, with higher numbers in the premaxillary-maxillary and dentary series than in the vomeropalatine and splenial series of teeth (Table 1).

We have studied the pictures that were made of one of the released specimens in the Madeira river. None of the pictures of the cloacal area was well focused and they did not allow a reliable count of the cloacal denticulations, but our impression is that there were 12 denticulations. On most pictures there is a short ventral furrow extending from the anterior tip of the cloacal disk. No such furrow was observed in our preserved specimens.

The specimen released in Mosqueiro was slightly larger (105 cm) than MPEG 33292, and seemed to be slightly darker than the specimens photographed in Rondônia.

Distribution: We currently know two widely (about 2,000 km airline) separated areas (Figure 11) for this large lungless caecilian, one (with two localities: Mosqueiro island, Praia de Marahú, and middle of the Baía de Marajó) in the estuary region of the Amazon river (more exactly, the joint southern affluents Tocantins and Guamá rivers), with generally slowly moving, muddy waters that are, however, subject to strong tidal influences (a few meters) and with variation of salinity over the year from fresh water to slightly brackish (1\%o) during the low water period of the Amazon river (Goulding et al., 2003), with a mean temperature of about $28^{\circ} \mathrm{C}$ (minimum $24^{\circ} \mathrm{C}$, maximum $34^{\circ} \mathrm{C}$ ), and an oxygen content of $8 \mathrm{mg} / \mathrm{l}$ in the Baía de Marajó; and one (Cachoeira Santo Antônio) in the middle reaches of the Madeira river, a southern affluent of the Amazon river, in an area with many cataracts (16 in a $360 \mathrm{~km}$ stretch between Porto Velho and Guajará-Mirim) (Figure 2A, 2C, 2D), and highly turbulent muddy waters with a temperature varying between a minimum of $25^{\circ} \mathrm{C}$ and a maximum of $30^{\circ} \mathrm{C}$, with the water beneath the cataracts supersaturated with oxygen and a difference during the year between high water and low water levels of about 12-13 m (Goulding et al., 2003).
Both areas are in (generally speaking) forested regions, the Madeira locality in terra firme forest, with rocky river shores, the Mosqueiro and Baía de Marajó localities in a mosaic of large water bodies, mangroves on mudflats, sandy beaches, varzea forests, and terra firme forest, with rocky (lateritic) areas strewn in between. Apparently, A. eiselti is able to cover its oxygen needs even in muddy water with relatively high temperatures, which makes it even more interesting, as oxygen content in warmer water is relatively low.

None of the three localities mentioned here can be described as an environment with "cold, fast- flowing upland streams", as (incorrectly) speculated to be the habitat of A. eiselti by Nussbaum \& Wilkinson (1995), a speculation that was followed by Himstedt (1996), Wilkinson et al. (1998), Zug et al. (2001: "highly aerated waters, such as mountain streams"), Wells (2007: "Their reliance on cutaneous respiration suggests that they probably lived in well-oxygenated water"), and Vitt \& Caldwell (2009: same phrase as Zug et al., 2001).

Nussbaum \& Wilkinson (1995), repeated by Himstedt (1996), suggested that $A$. eiselti possibly already was extinct because the only specimen known at that time had been collected over about a 100 years ago and because of the fast destruction of Neotropical montane forests (Himstedt (1996), even specifying the habitat as "Bergregenwälder in Südamerika" [=South American mountain rainforests]). Wilkinson et al. (1998), discussing the second known specimen, were a bit more optimistic and had hopes that new populations still might be discovered. The recent discovery of several specimens of this species in two widely separated localities in the lowland part of the Amazonian basin shows that the pessimistic expectations of former authors were unfounded, and that the fact that few specimens have been collected probably is due to a combination of an unusual habitat and insufficient collecting in the right places. We have to add that the habitat of this species in the Madeira river may be threatened by the imminent construction of a number of hydroelectric 
dams. However, the localities in and near Mosqueiro are in an area with relatively strong human impact (e.g., all of Belém's untreated waste flows downstream to Mosqueiro, and the island is a favourite holiday spot for the population of Belém [1.6 million] throughout the year), and the species can resist such apparently adverse conditions.

Habitat: Praia de Marahú is situated on the North coast of Mosqueiro island, opposite Marajó island, and borders the Baía de Marajó. In front of the relatively narrow sandy beach, there is an extensive area strewn with rocks and rock ledges that surfaces at low tide. At about $730 \mathrm{~m}$ in front of the beach there is a small, horseshoe-shaped, rocky island, surrounded by a rock strewn bottom. One (released) specimen was caught here in a shrimp trap installed between rocky ledges in front of a sandy beach (Figure 1). Two specimens were caught in large meshed vertical gill nets deployed in the middle of the Baía de Marajó on a sand bank, with a depth of about $18 \mathrm{~m}$. According to Dr. R. B. Barthem (personal communication), this is the channel of the river where also many shrimps and the commercial fishes "dourado" [Brachyplatystoma rousseauxi (Castelnau, 1855)] and "piramutaba" [B. vaillantii (Valenciennes, 1840)] occur.

At Cachoeira Santo Antônio, specimens were collected in a remaining pool at the deepest point of the river bed near a small island in the Madeira river (Figure 2A shows the cataract while it was still active). The river channel on the left bank of the Madeira river was closed on July 30, 2011 and over a two day period the water ran out of the channel, just leaving isolated pools. The riverbed at that point consists of a tumble of bare rocks devoid of any vegetation (Figure 2C, 2D) and has a depth of about $55 \mathrm{~m}$. The remaining pool of standing water in which the specimens were caught had a depth of $1.5 \mathrm{~m}$ and its bottom was at $4 \mathrm{~m}$ below sea level, the surrounding area is at about $50 \mathrm{~m}$ above sea level. Limnological studies in the Madeira river show that both the content of dissolved oxygen and the saturation with oxygen at the surface of the river and at the bottom are nearly identical. However, stations below the cataracts were better oxygenated than those above the cataracts.

Nussbaum \& Wilkinson (1995), repeated by Himstedt (1996), observed that $A$. eiselti "must occupy an aquatic habitat very different to that of its closest relatives". Because of our discovery of this species in areas where it occurs sympatrically with Potomotyplus and Typhlonectes, this supposition has to be reviewed. We have to look at the habits and way of life of $A$. eiselti and its closest relatives in order to explain their sympatric (and partly syntopic) occurrence in at least two areas in Brazilian Amazonia.

Apparently $A$. eiselti is active in daytime, because the photographed specimen of Praia de Marahú, Belém, moved into a baited shrimp trap between 8:00 and 15:00 $h$, either in search of the bait, or of captured shrimps, and a second specimen was seen swimming on the surface in daytime near the small island in front of Praia de Marahú. From the fact that two specimens were collected in the middle of the Baía de Marajó (12.5 km from either Marajó or Mosqueiro), we can conclude that $A$. eiselti is a good swimmer, venturing far from shore. The Cachoeira Santo Antônio specimens were collected in daytime, while swimming at the surface of a remaining pool in the riverbed, a situation that hardly can be called natural, also when realizing that the entire area of the Cachoeira has been heavily disturbed because of all the construction work taking place, the past two years.

The stomach and intestine of MPEG 33292 and MPEG 33578 did not contain any food items, just some grains of sand/mud. The stomach of MPEG 33579 contained a shapeless, transparent sheet of tissue that did not show any identifiable macroscopic characters. Its intestine contained some sediment. The specimen photographed and released in the Madeira river excreted a beige substance. During excretion the cloacal denticulations were apparently contracted and raised above their normal position, forming some kind of crown.

Atretochoana eiselti in the Mosqueiro region is sympatric and syntopic with Potomotyphlus kaupii 
(Berthold, 1859), but as far as known now, not syntopic with Typhlonectes compressicauda (Duméril \& Bibron, 1841), both species that are well known from the Belém/ Mosqueiro region (Maciel \& Hoogmoed, 2011), although there may be important differences in microhabitat and habits. Typhlonectes compressicauda is known to dig into hypoxic substrate (Nussbaum \& Wilkinson, 1995; Wilkinson \& Nussbaum,1997), but it seems unlikely that $A$. eiselti could do that, because that probably would largely shut off its oxygen supply. In the Cachoeira Santo Antônio area, A. eiselti apparently could be sympatric with Potomotyphlus kaupii, of which four specimens were collected and released again earlier at a nearby area in the Madeira river (JTC, personal observation).

\section{DISCUSSION}

Atretochoana eiselti at first sight is easily distinguished by external morphologic characters from sympatric Typhlonectes compressicauda and Potomotyphlus kaupii by its large anteriorly directed nostrils, its flat and widened head, and its much greater size in adults. Wilkinson \& Nussbaum (1999) studied the relationships of Typhlonectidae genera based on 141 morphological characters and assumed that Atretochoana and Potomotyphlus are sister taxa. This conclusion up till now could not be confirmed with a molecular sample of Atretochoana, but we now have tissue samples of three specimens that will be used for this molecular check.

We checked the material of Typhlonectes compressicauda in several Brazilian collections (MPEG; Museu Nacional, Rio de Janeiro; Museu de Zoologia da Universidade de São Paulo, São Paulo; Instituto Nacional de Pesquisa da Amazônia, Manaus), but we did not find any additional specimens of $A$. eiselti (Maciel \& Hoogmoed, 2011).

Wilkinson \& Nussbaum (1997) mentioned that caecilians use buccopharyngeal pumping to fill the lungs with air, and they explained that this system would not work in a lungless caecilian, and based on the dissection of the type specimen they came to the conclusion that "The dense capillary network close to the surface of Atretochoana must enhance the rate of gas exchange across the skin". Despite this clear statement about the likely way of respiration of $A$. eiselti by Wilkinson \& Nussbaum (1997), Exbrayat \& Estabel (2006) surprisingly state "In Atretochoana eiselti, a species without lungs, buccopharyngeal respiration is mainly used". It is not clear on what they base this statement, but it seems to be a mistake, or a misreading of Wilkinson \& Nussbaum (1997). Although the buccopharyngeal respiration mechanism in $A$. eiselti is still functional (Wilkinson \& Nussbaum, 1997), without lungs it can not cover the oxygen necessities of an animal of the size of A. eiselti. The problem of how $A$. eiselti obtains oxygen from its watery surroundings has not been solved yet. The only things we know is that the species has no lungs, it has closed choanae, and has capillaries that are very close to the skin (only 2-3 cells between blood and surface of the skin), all of which seem to lead to the conclusion that the only way for this species to obtain oxygen from its surroundings is through its skin (Wilkinson \& Nussbaum, 1997). Possibly the wrinkles in the skin serve to increase total skin surface in order to facilitate skin respiration, as occurs in the cold water inhabitants Telmatobius culeus (Garman, 1876) and Atelognathus patagonicus (Gallardo, 1962) (Ceratophryidae), and Cryptobranchus alleganiensis (Daudin, 1803) (Cryptobranchidae) (Duellman \& Trueb, 1986). However, as the buccopharyngeal mechanism is still functional (see above), part of the oxygen requirements may be filled by buccopharyngeal respiration as in plethodontid salamanders (Zug et al., 2001). We neither should neglect the possibility of intestinal or maybe even cloacal respiration as is known to occur in several aquatic turtles (personal observation MSH, Moll \& Moll, 2004). Lunglessness generally is restricted to the small salamanders of the family Plethodontidae, to the salamander genus Onychodactylus of the family Hynobiidae (Nussbaum \& Wilkinson, 1995), to the small Bornean frog Barbourula kalimantanensis Iskandar, 1978 (Bickford et al., 2008), and the small terrestrial Guyanan Gymnophiona Caecilita 
iwokramae Wake \& Donnelly, 2009 (Wake \& Donnelly, 2009), where the relation skin surface to total volume is much more favourable for dermal respiration than in A. eiselti, which is very large, with a more unfavourable relation skin surface to body volume. Among the lungless tetrapods, $A$. eiselti stands out by its size, with a mass that is several orders of magnitude larger than that of most other lungless tetrapods. Nussbaum \& Wilkinson (1995) assumed that the lunglessness of $A$. eiselti is an adaptation to inhabiting the bottom of fast flowing upland streams. Lungs, because of the buoyancy they provide to their owners, would be maladaptive to such a habitat. However, the fact that $A$. eiselti has been collected in deep water in standing gill nets (suggesting it is a good swimmer) seems to defy this assumption, although its occurrence in cataracts and strong tidal currents could be explained by it. The fact that Typhlonectes compressicauda, a close relative of $A$. eiselti, that generally moves around on the bottom, has two well developed lungs that give it positive buoyancy, seems to contradict any relation between way of life and presence or absence of lungs in these Gymnophiona. In conclusion, we can say that the evidence for a relation between absence or presence of lungs and way of life in the aquatic environment in Typhlonectidae at least is contradictory and should be reviewed thoroughly.

In the physical environment there are several factors to be considered that play a role in the process of skin respiration in the Amazon and its associated rivers: temperature of the water, turbulence of the water, amount of dissolved oxygen, amount of particles in suspension, organic material deposited on the bottom (which uses up a lot of oxygen), and substrate. Normally, fast running water is cold and with high oxygen content. This does not hold true for the localities from which A. eiselti is known. Water temperatures at those localities are high (see above), the water is turbid, and oxygen content is variable. This seems to be a rather adverse condition for $A$. eiselti. A possible explanation could be that $A$. eiselti inhabits fast running waters with rather low and variable oxygen content, but because of the large amount of water that runs along its body it possibly could collect enough oxygen to cover its respiration needs. This condition is present in both areas: in the Madeira river the water in the cataracts runs fast (Figure 2A) and in the Baía de Marajó there are strong tidal currents. However, in order to not be swept away by the current, animals have to anchor themselves one way or the other. For $A$. eiselti the only possibility seems to anchor itself in a rocky environment, present in both areas from where it is known, although it also occurs in areas of the Baía de Marajó that are sandy and where possibilities for anchoring itself are apparently absent.

Rivers with a high mud contents are known to support a higher biomass, which for a predator or scavenger like $A$. eiselti would be an additional positive factor (R. B. Barthem, personal communication). However, this all remains speculation and needs to be checked in the field and/or in the laboratory, using live specimens.

\section{CONCLUSION}

Although the discovery of $A$. eiselti in two areas in the Brazilian Amazon basin has partly solved the question of its distribution, and shown that earlier speculations about its habitat were wrong, there are still many unknowns about this rare species. We now have some indications about its habitat, but these present conflicting data, and additional information should be collected. We are also still facing many questions about its life history, including reproduction, about its physiology (especially its respiration) and its functional morphology. We now know where to look for additional specimens that can be studied in the laboratory and where to try to collect data on the habits of this species in nature. We still have a long way to go before we can consider this species 'known'. At the moment, we have just started to get superficially acquainted with this strange, enigmatic species. Many anatomical, physiological, ecological, ethological, and molecular studies will be needed to get a better knowledge of $A$. eiselti. 

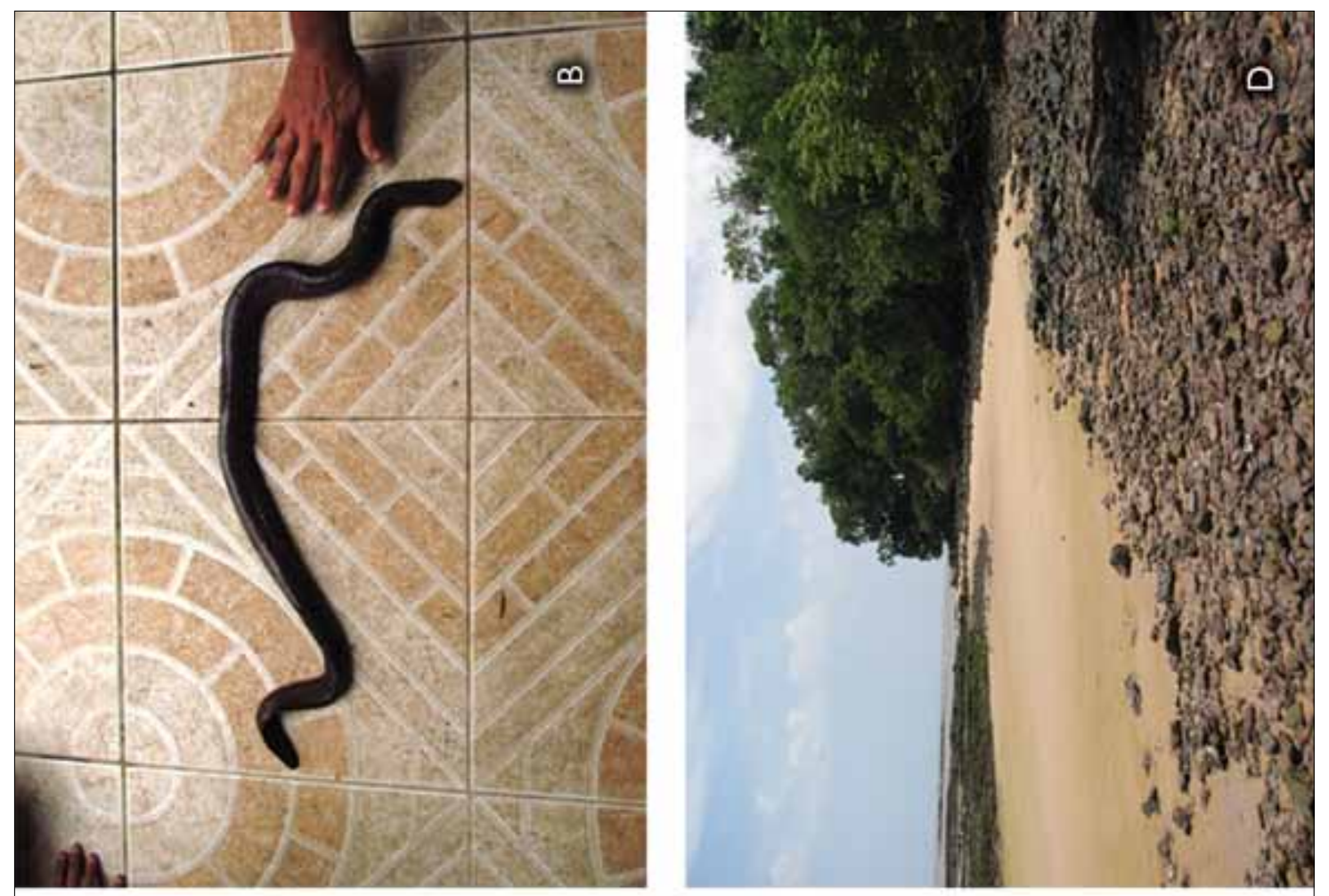

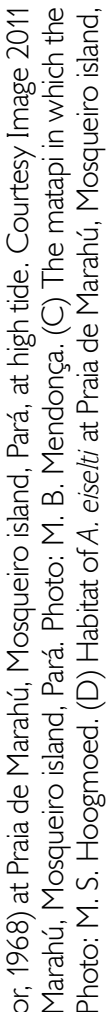
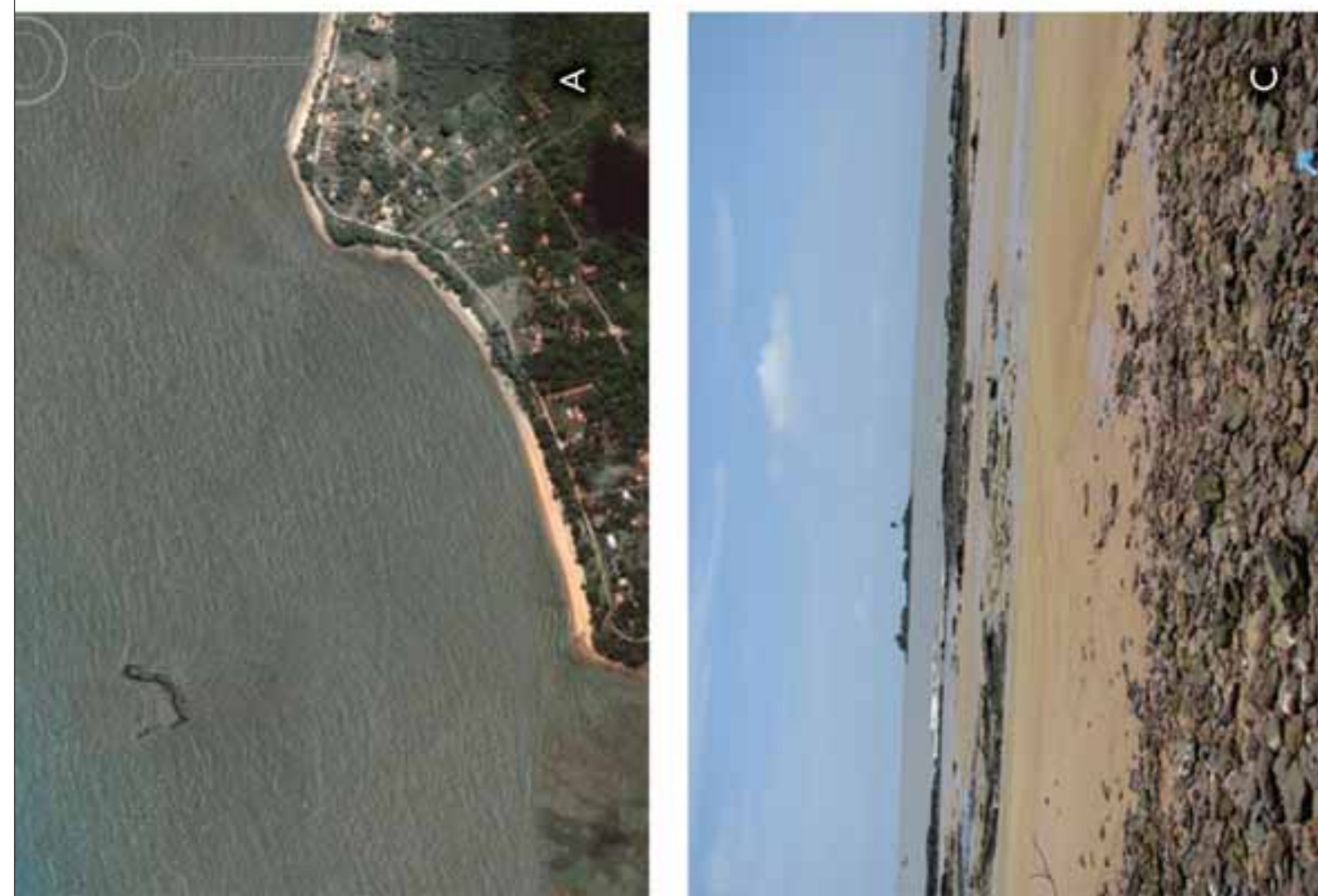

\section{이싱}

这离

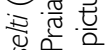

(

$\overbrace{\pi}^{\pi}$

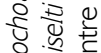

क्षे क्ष

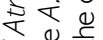

4.

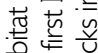

웡

Q

辛全变

至

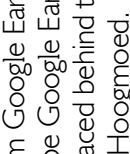

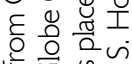

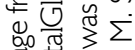

है:

垔 (1)

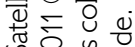

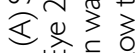

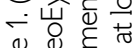

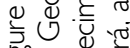

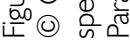



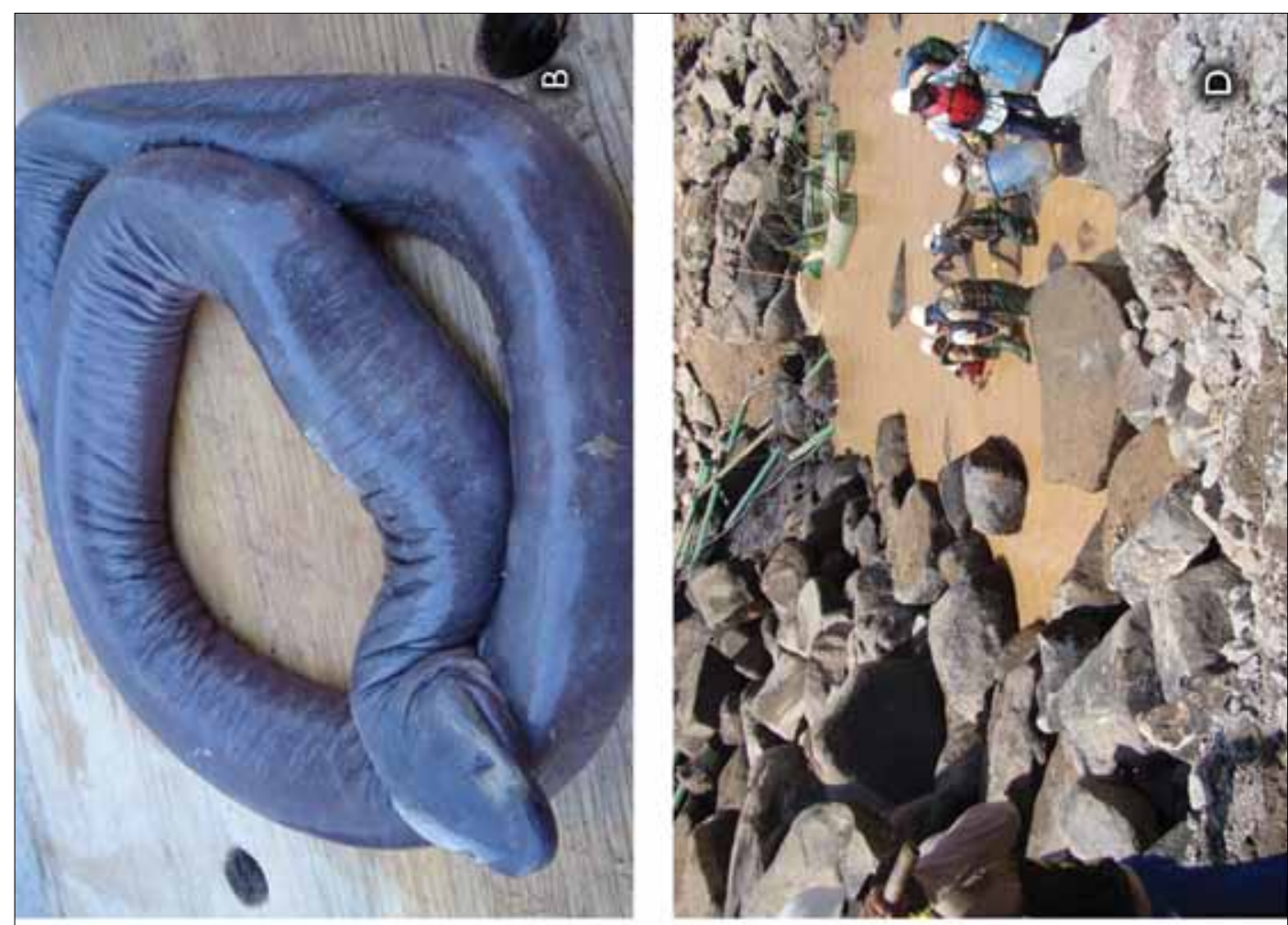

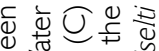

$\overrightarrow{⿱ 亠 乂}$

तो.

용

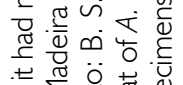

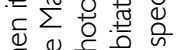

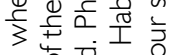

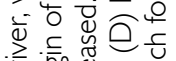

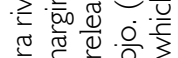

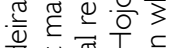

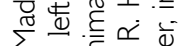

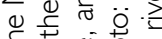

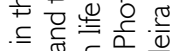

을

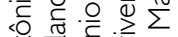

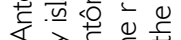

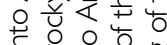

票

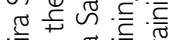

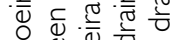

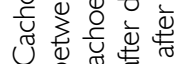

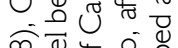

o

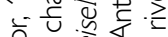

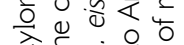

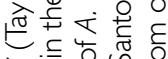
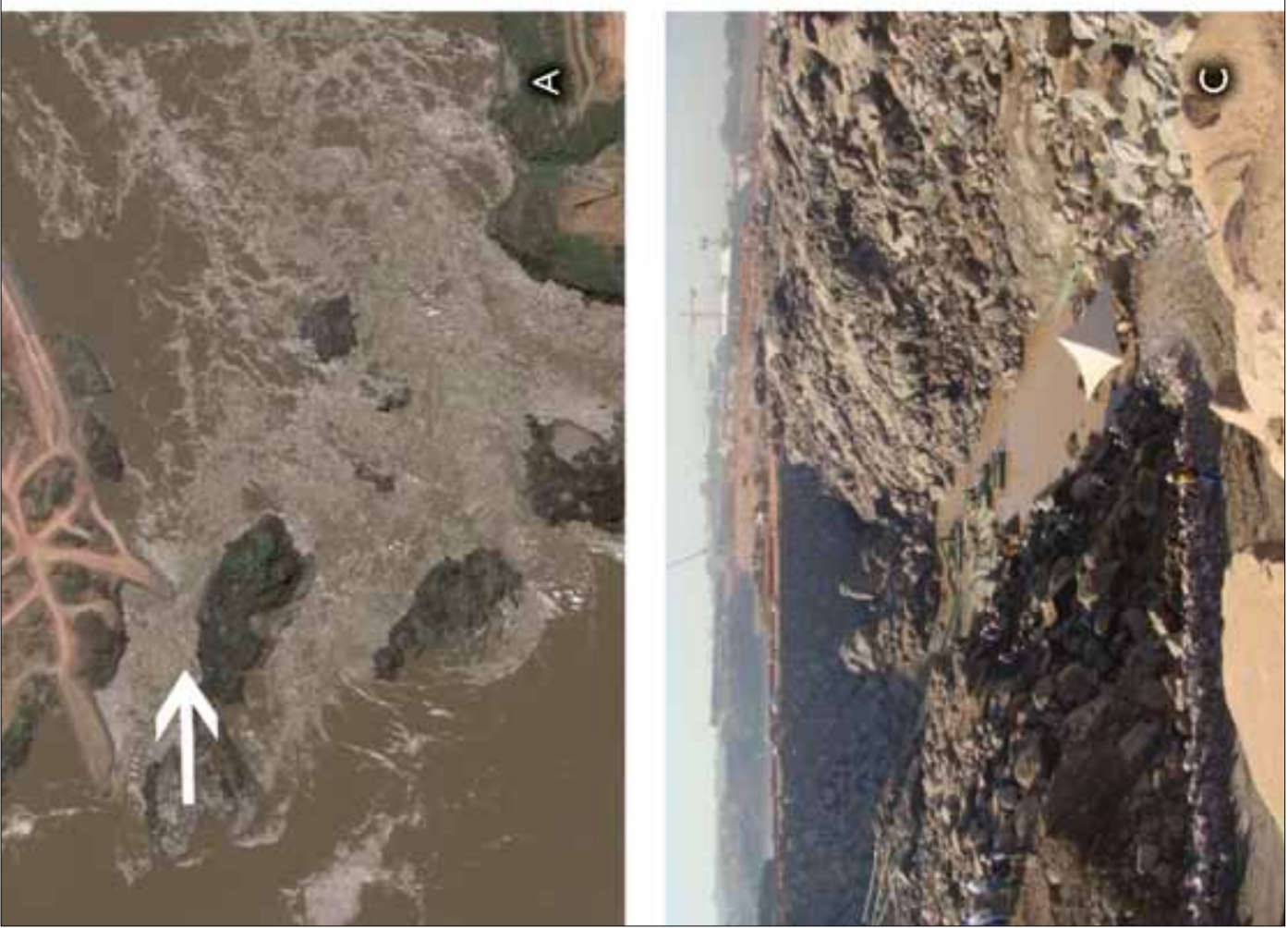

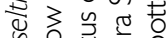

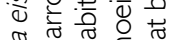

雨

过定更

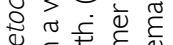

安专焉产

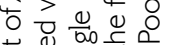

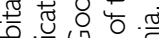

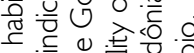

$\checkmark=0 . \bar{c}$

40

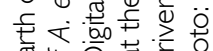

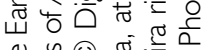

$\frac{0}{00} \stackrel{2}{0}$ (2) $\frac{\pi}{\bar{c}} \cdot \frac{1}{0}$

O

ह के ते

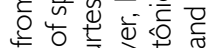

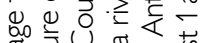

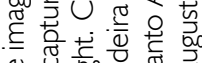

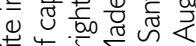

焉

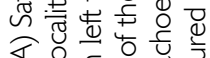

«

तु

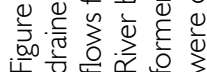



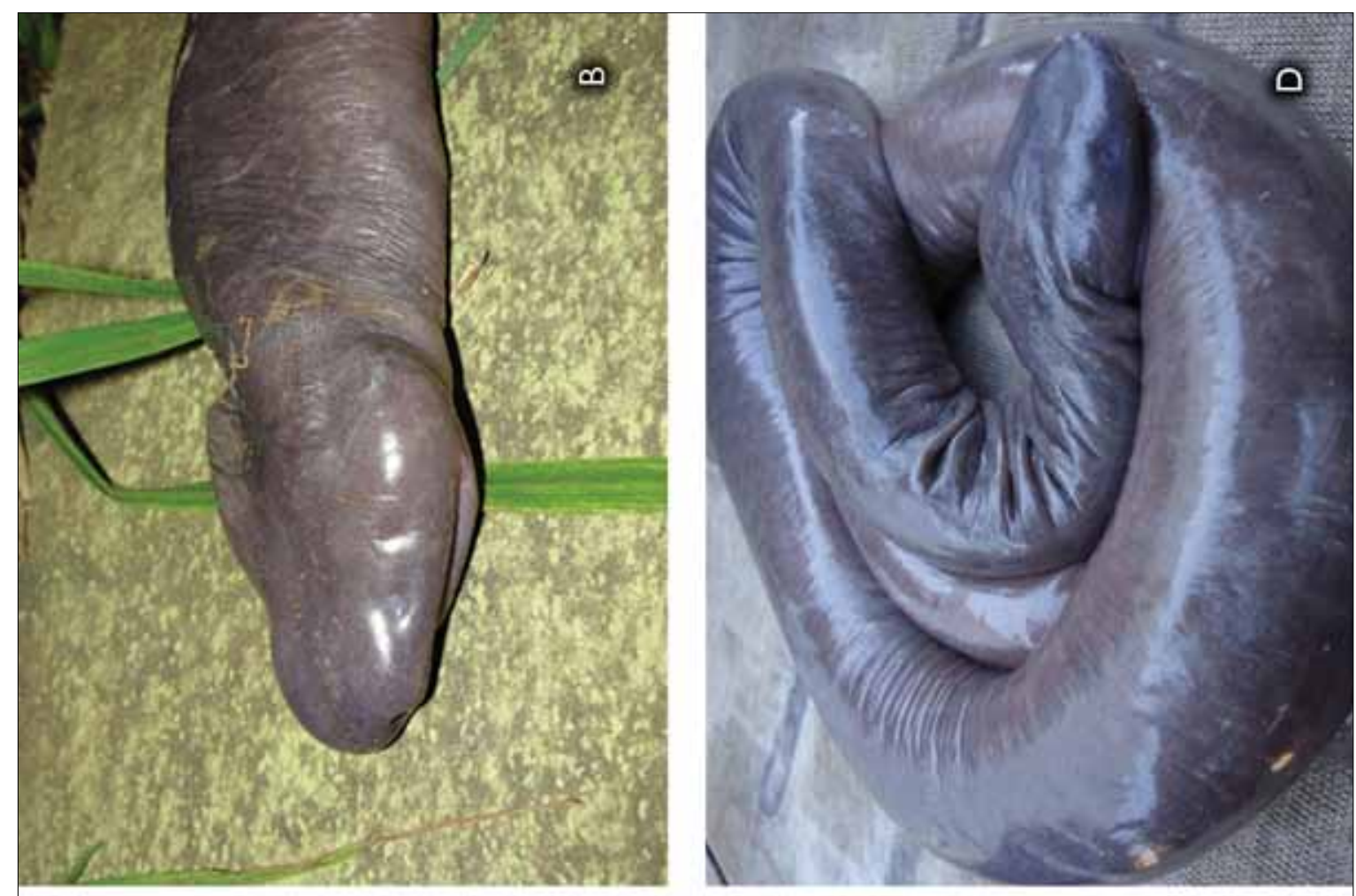

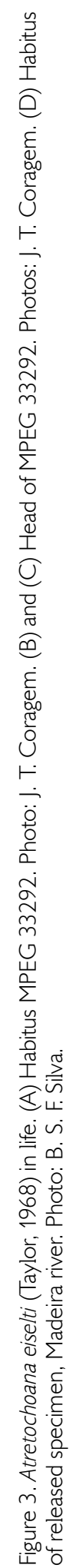
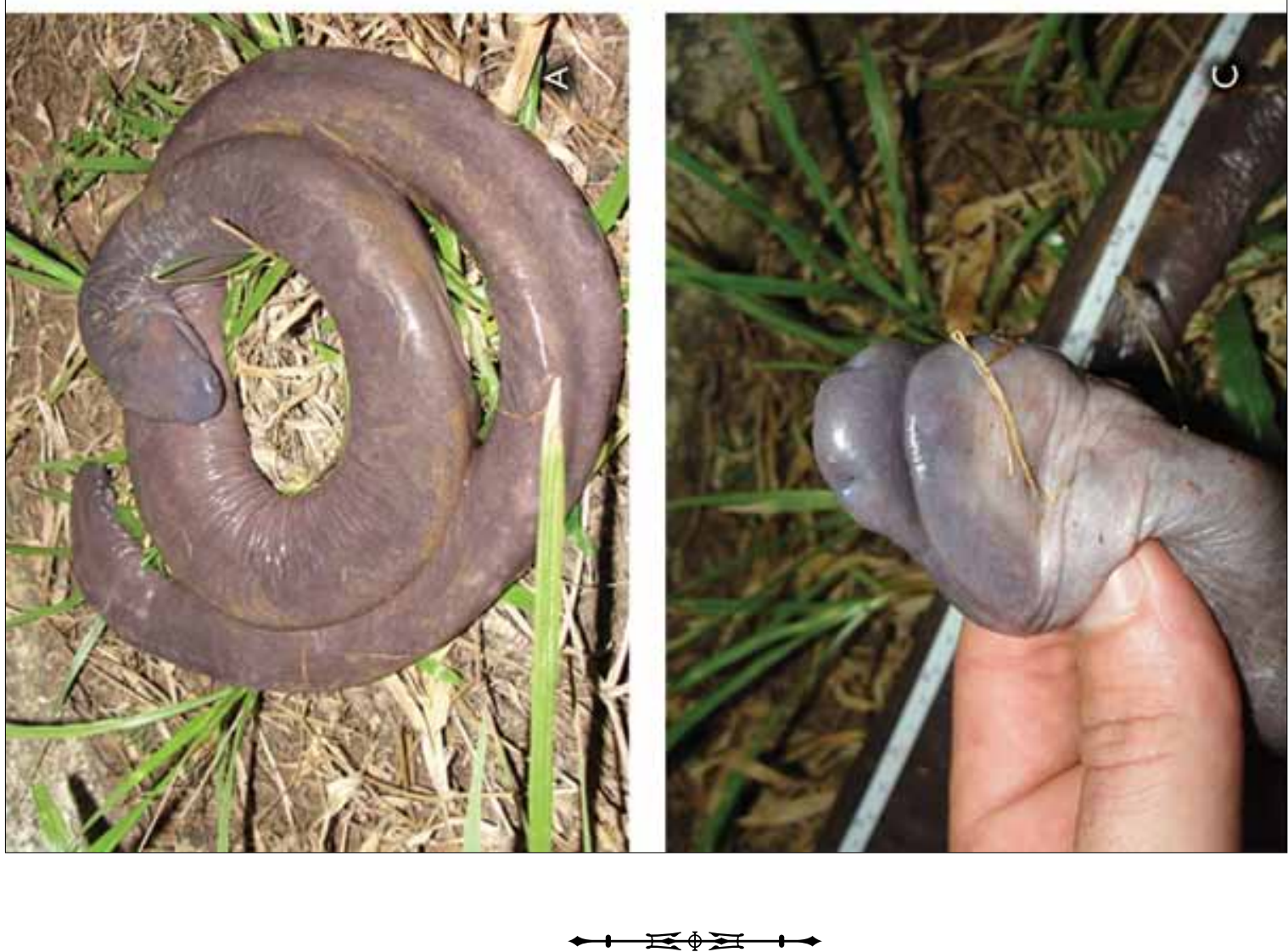


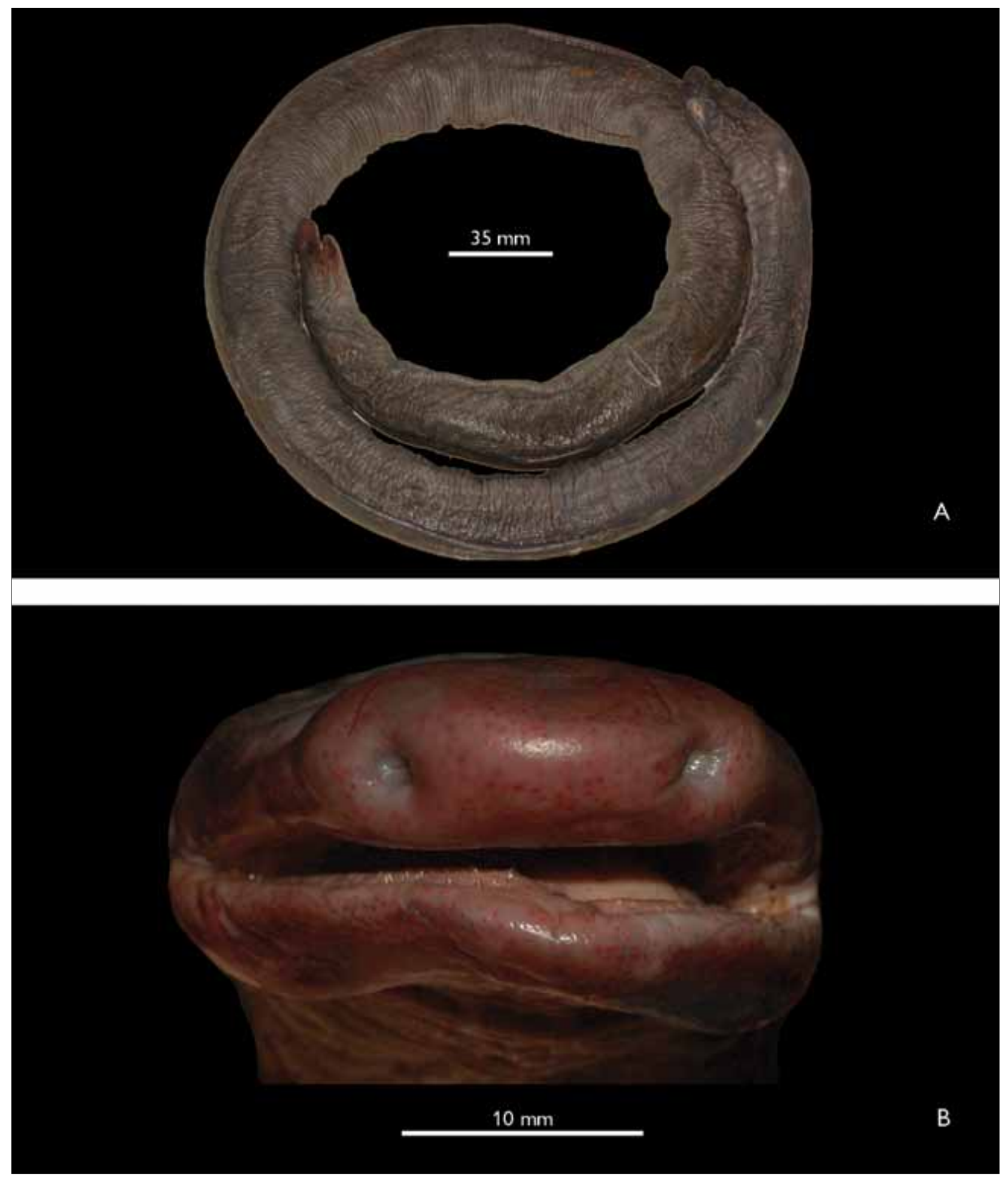

Figure 4. (A) Atretochoana eiselti (Taylor, 1968), MPEG 33292 from Cachoeira Santo Antônio, Madeira river, Rondônia, after six weeks in preservative. (B) Head in frontal view. Photos: A. O. Maciel.

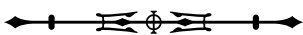




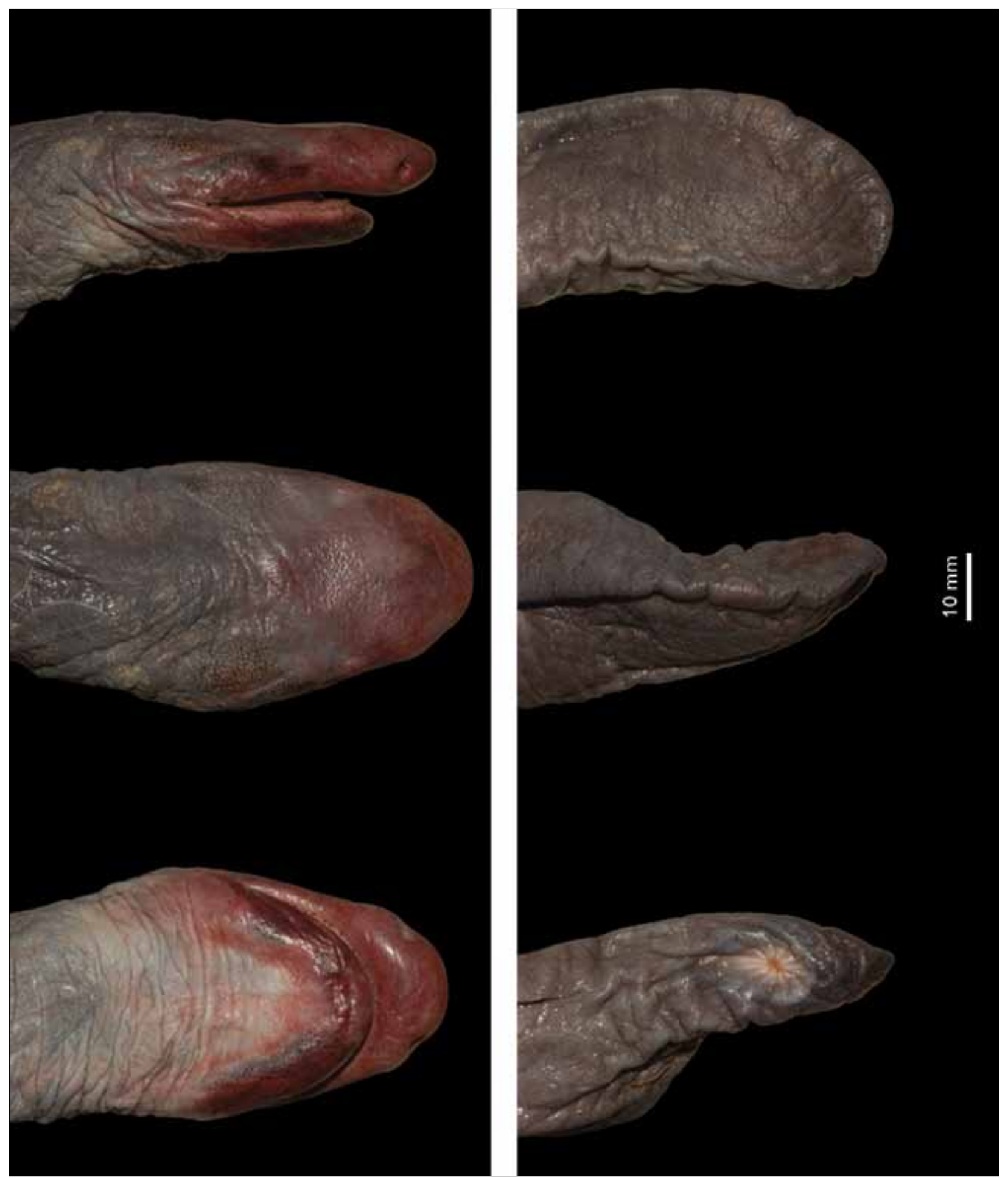

Figure 5. Atretochoana eiselti (Taylor, 1968) (MPEG 33292). Left column: lateral, dorsal, and ventral view of head. Right column: lateral, dorsal, and ventral view of end of body. Photos: A. O. Maciel.

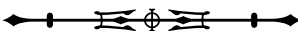




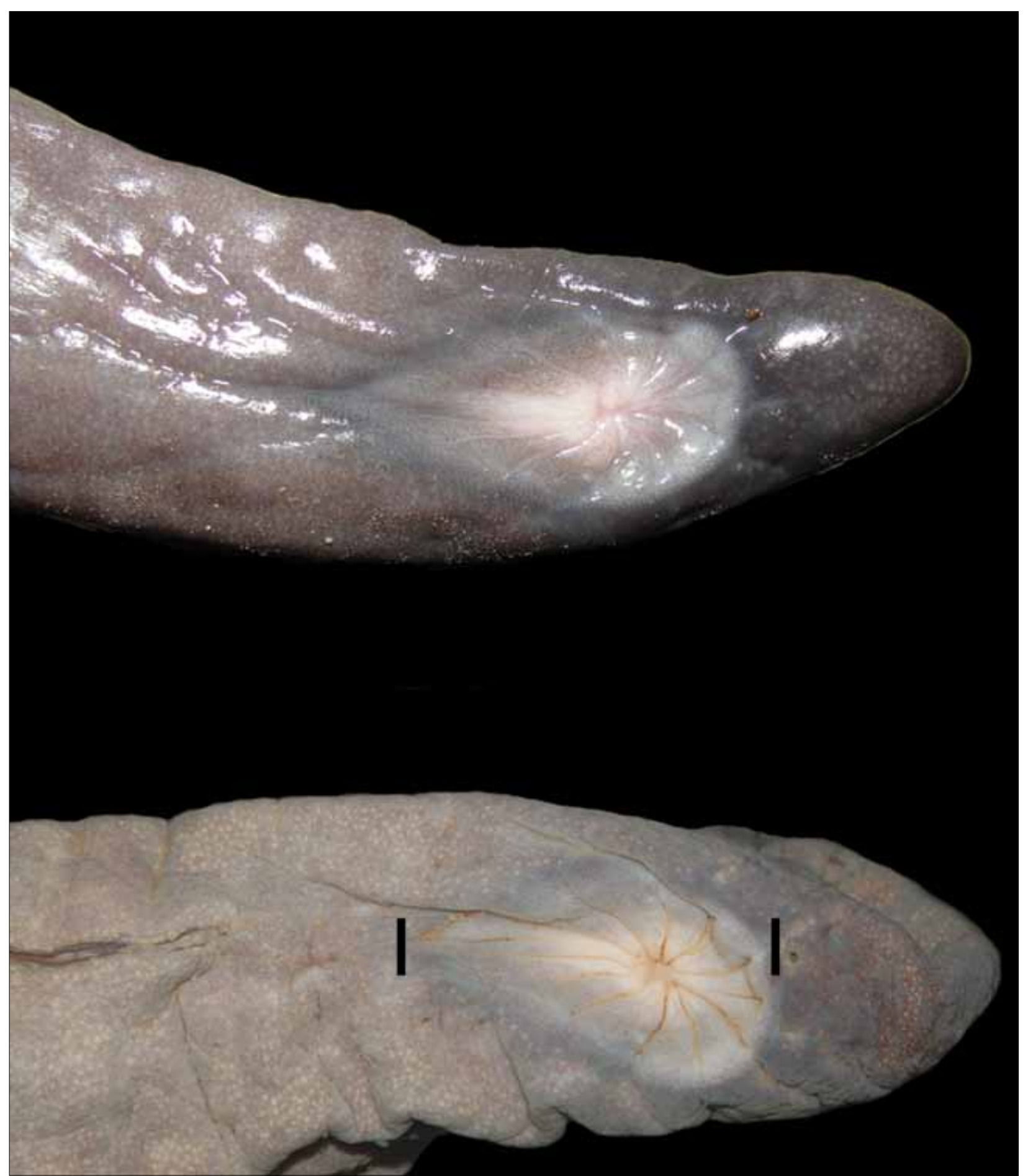

Figure 6. Atretochoana eiselti (Taylor, 1968), female MPEG 33292 from Cachoeira Santo Antônio, Madeira river, Rondônia, in life (above) (Photo: J. T. Coragem), and in preservative (below) (Photo: A. O.Maciel), showing changes in cloacal region after preservation. The distance between the two bars in the preserved specimen is $15 \mathrm{~mm}$.

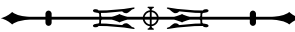




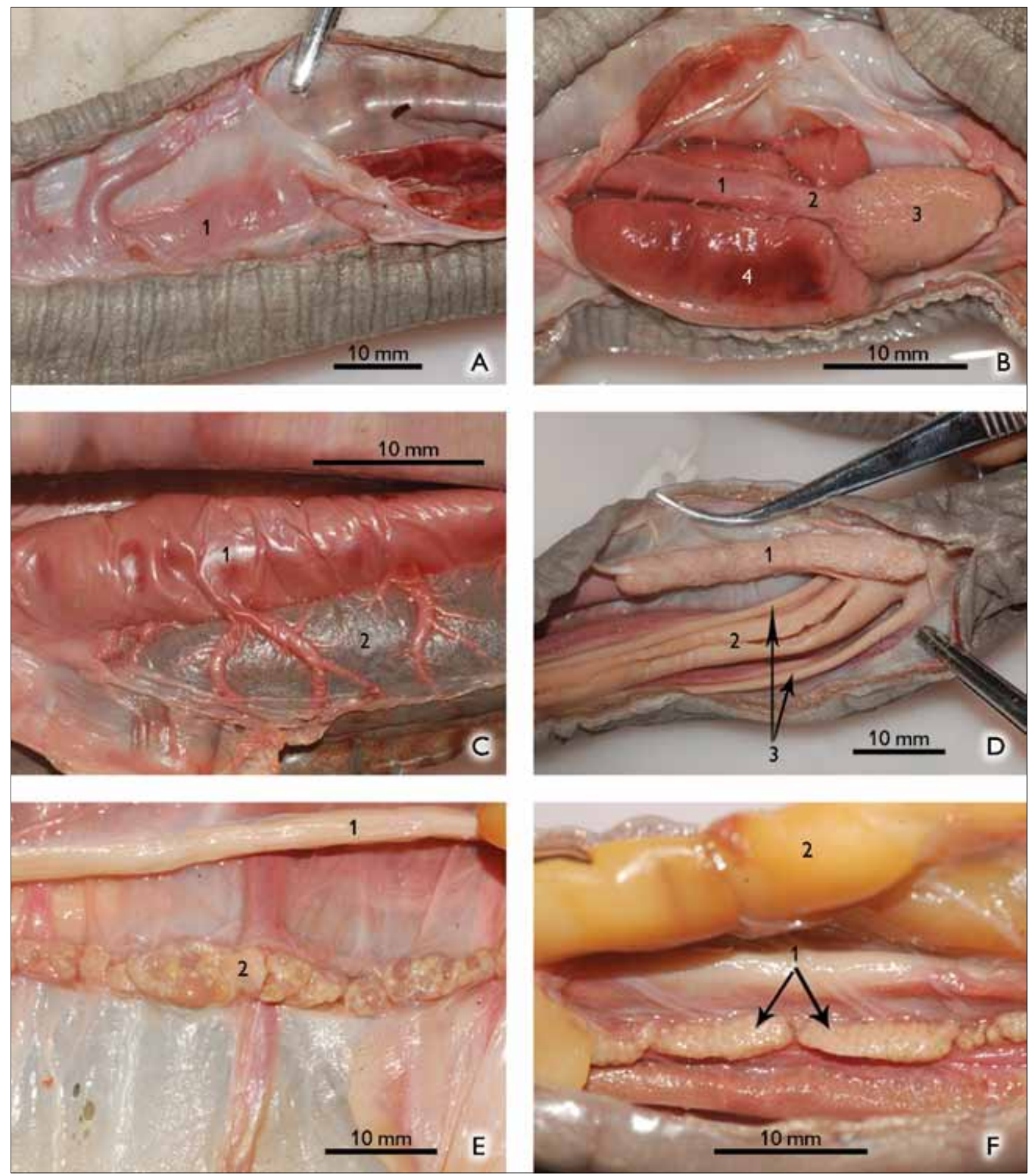

Figure 7. Atretochoana eiselti (Taylor, 1968) - Detailed view of viscera of female MPEG 33292 arranged from anteriorly to posteriorly as follows: A, B, C, E/F and D: (A) Anterior vena cava (1). (B) Heart (right atrium [4], ventricle [3]) with conus arteriosus (2) and truncus arteriosus (1). (C) Posterior vena cava (1) above the liver (2). (D) Urinary bladder (1), intestine (2), and oviduct (3). (E) Oviduct (1) and parallel ovary (2). (F) Male MPEG 33578, testis (1) and fat bodies (2). 


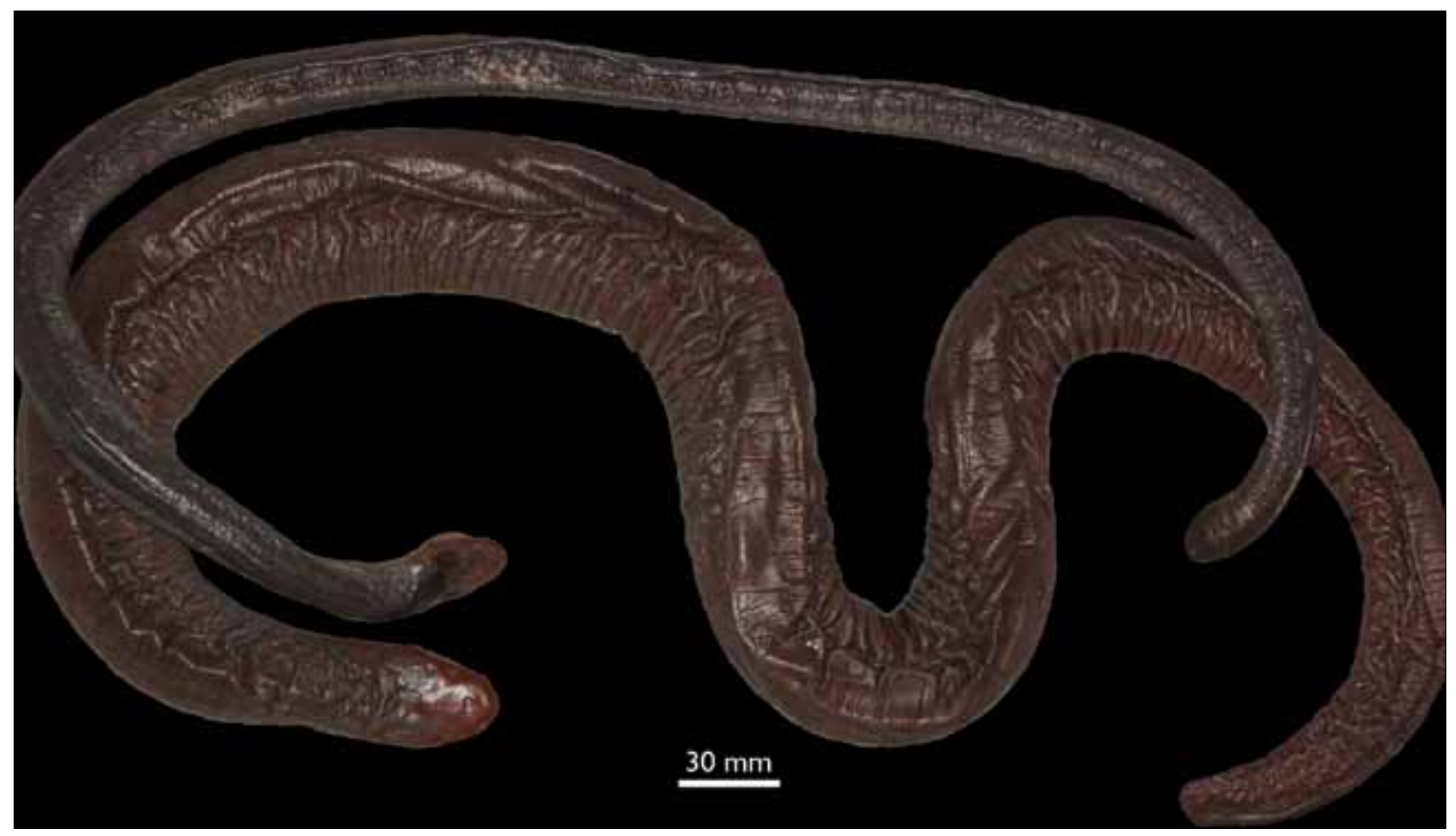

Figure 8. Atretochoana eiselti (Taylor, 1968). General aspect of male MPEG 33578 (smallest specimen) and female MPEG 33579 (largest specimen).

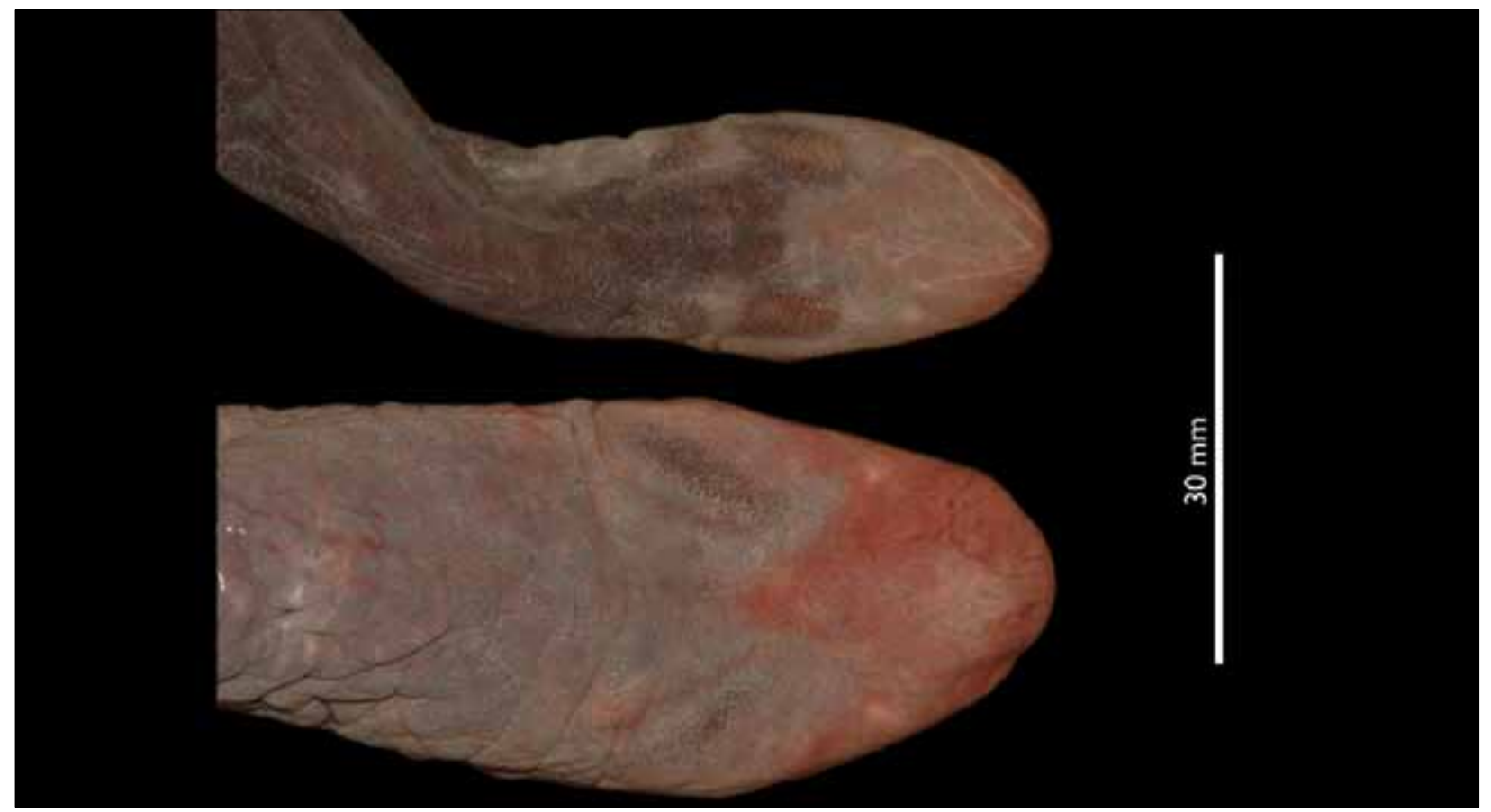

Figure 9. Atretochoanae eiselti (Taylor, 1968). Head of male MPEG 33578 (above) and female MPEG 33579 (below), showing the considerable differences in size and shape.

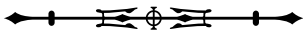




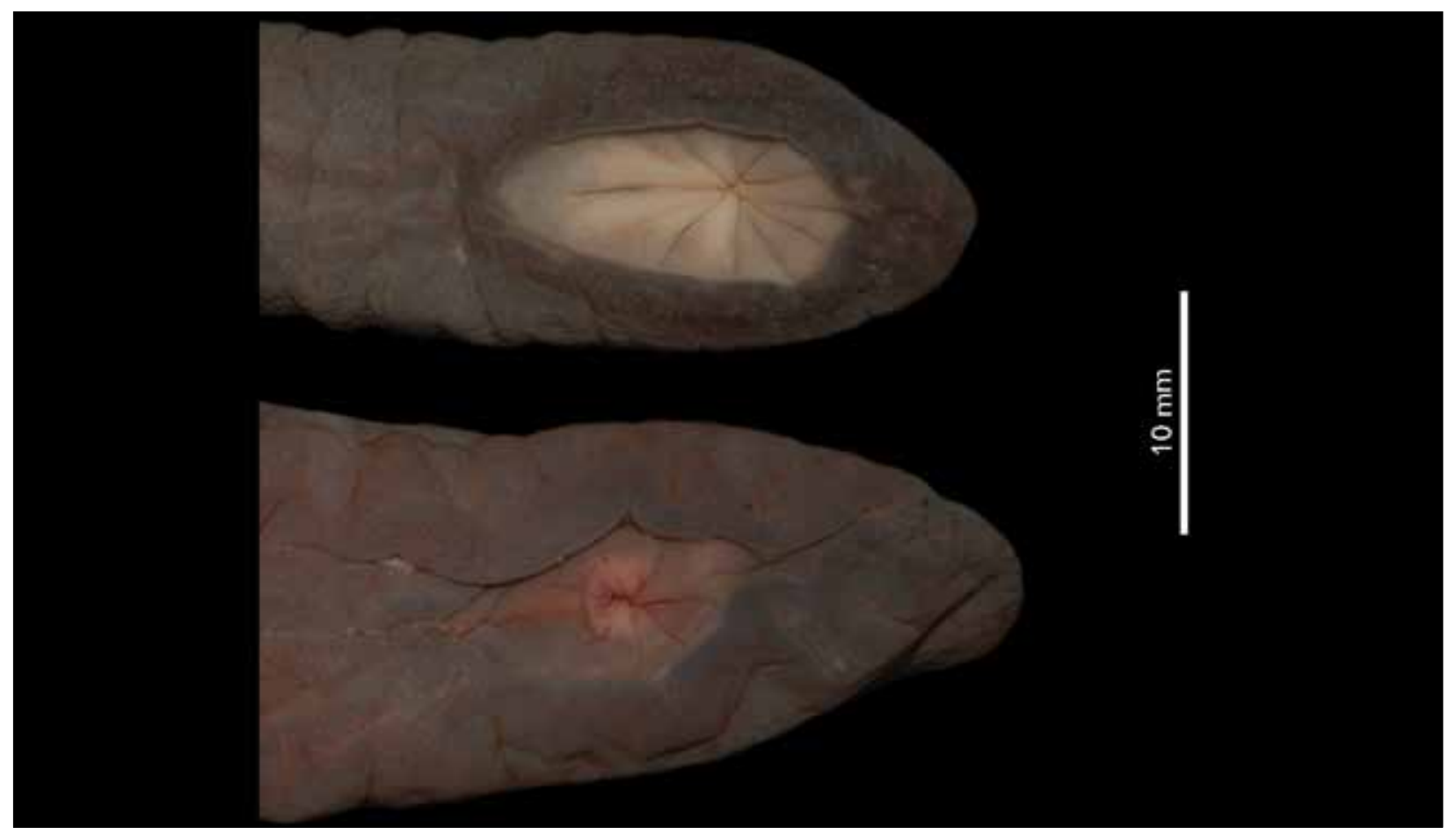

Figure 10. Atretochoana eiselti (Taylor, 1968). Cloacal discs of male MPEG 33578 (above) and female MPEG 33579 (below).

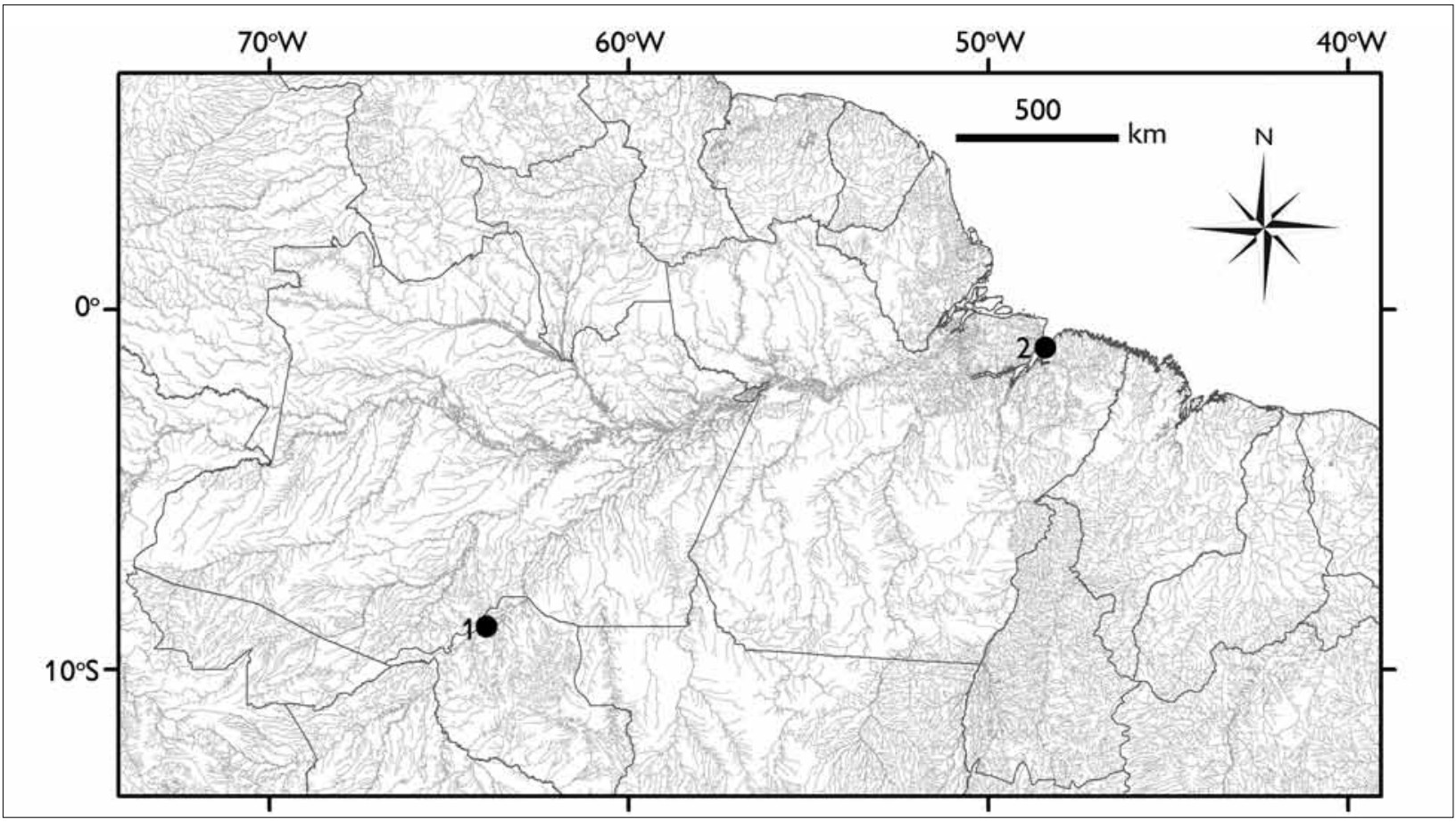

Figure 11. Map showing the localities where Atretochoana eiselti (Taylor, 1968) was collected. 1. Cachoeira Santo Antônio, Madeira river, Rondônia, Brazil; 2. Praia de Marahú, Mosqueiro island, and middle of Baía de Marajó, Pará, Brazil.

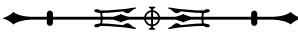




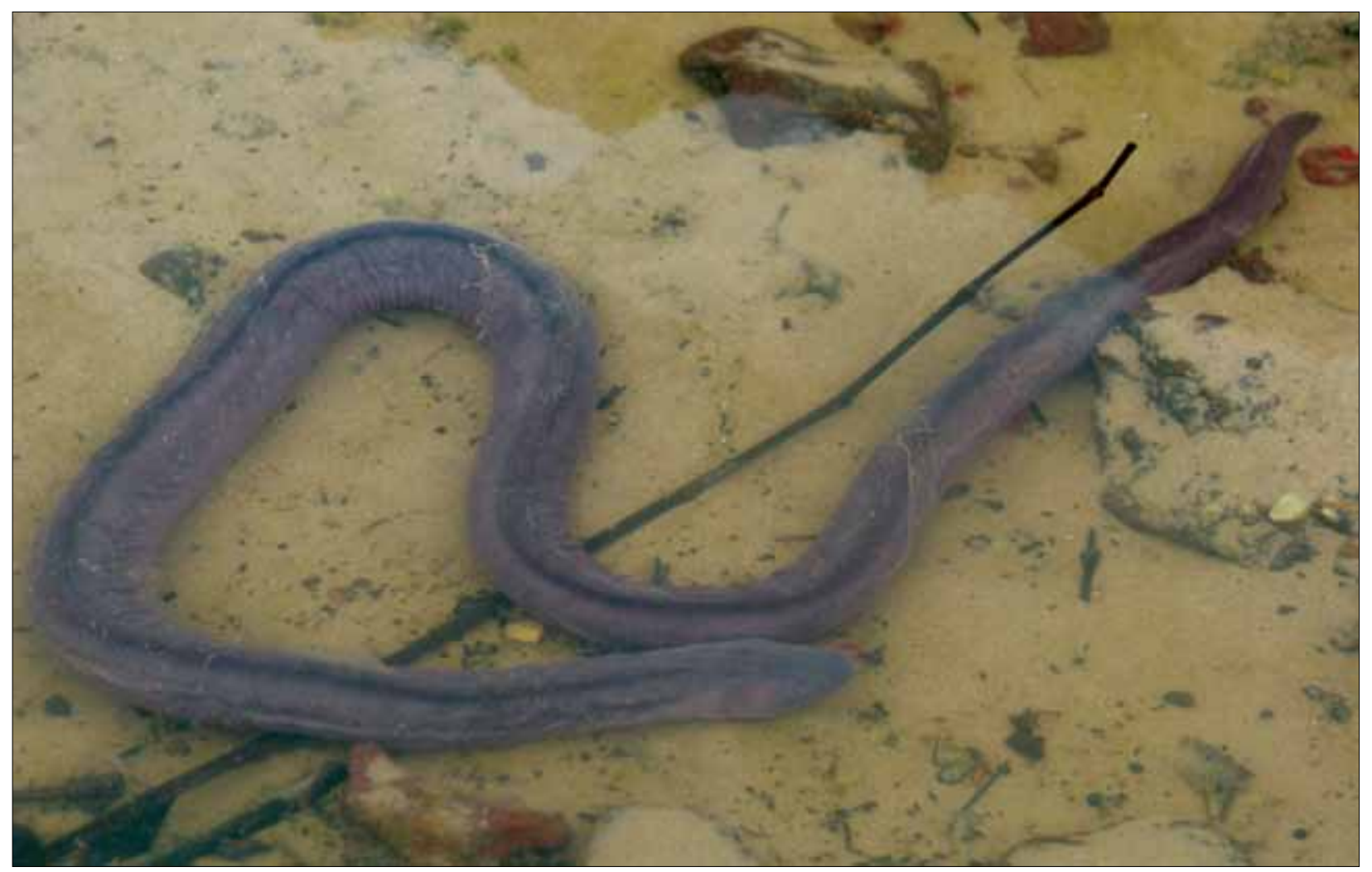

Figure 12. Atretochoana eiselti (MPEG 33621) swimming in a tidal pool, Praia Marahú, Mosqueiro island, Belém, Brazil.

\section{NOTE ADDED IN PROOF}

On December 23, 2011, 17:00 h, another specimen of $A$. eiselti (fieldnumber MSH 11459, registered as MPEG 33621) (Figure 12) was collected in a tidal pool during low tide, on Praia Marahú, Ilha de Mosqueiro. This specimen is a female of $744 \mathrm{~mm}$ and $260 \mathrm{~g}$. It was collected alive, but died after about 30 hours being kept in two different containers and having been transported over about $70 \mathrm{~km}$. The senior author had the opportunity to observe it for several hours before its death. When handled the specimen was very limp and could not erect hanging parts of the body, although it was able to move its body with force between closed fingers that held it. Placed in a tidal pool on the beach it swam slowly around with undulating movements and the dorsal fin and a much lower ventral fin were well visible. Outside the water the ventral fin only was recognizable as a low ridge. Placed in a container (without aeration) the specimen was inactive, it was lying on the bottom of the container and made slow, regular movements with the body that formed wide loops. Possibly an attempt to improve oxygen uptake via the skin. It did not try to surface to gulp air. It did not react to dead shrimp provided as food.

\section{ACKNOWLEDGEMENTS}

We like to thank Marina Berreira Mendonça of Belém for sending us the pictures of the first live $A$. eiselti known and thus causing us to delve into this matter. The specimen from Rondonia was collected under Autorização de captura, coleta, e transporte de material biológico No. 112/2011, processo IBAMA No. 2001.000965/2008-83 dd. May 12, 2011 issued to Santo Antonio Energia S.A. and SETENGE Serviços Técnicos de Engenharia e Geologia Ltda in Porto Velho. The material from Mosqueiro island was collected under Licença permanente para coleta de material zoológico de SISBIO No.

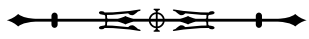


13906-1 dd. April 14, 2009issued to Marinus S. Hoogmoed. We want to thank R. Hojo and B. S. F. Silva for providing us with photos, and R. Hojo, F. Talin and D. Nunes for collecting MPEG 33292 and other material, and for drawing our attention to it. I. de Silva collected the specimen MPEG 33621) mentioned in the Note added in proof.

\section{REFERENCES}

BICKFORD, D., D. ISAKANDAR \& A. BARLIAN, 2008. A lungless frog discovered on Borneo. Current Biology 18(9): R374-R375.

DUELLMAN, W. E. \& L. TRUEB, 1986. Biology of Amphibians: i-xvii, 1-670. McGraw-Hill Book Company, New York.

EXBRAYAT, J.-M. \& J. ESTABEL, 2006. Anatomy with particular reference to the reproductive system. In: J.-M. EXBRAYAT (Ed.): Reproductive biology and phylogeny of Gymnophiona (Caecilians): 79-155. Science Publishers, Enfield (NH), Jersey, Plymouth.

FROST, D. R., 1985. Amphibian species of the world. A taxonomic and geographical reference: 1-732. Allen Press, The Association of Systematics Collections, Lawrence.

FROST, D. R., 2011. Amphibian species of the world: an Online Reference. Version 5.5. Available at: <http://research.amnh.org/vz/ herpetology/amphibia/>. Accessed on: 15 August 2011.

GOULDING, M., R. BARTHEM \& E. FERREIRA, 2003. The Smithsonian Atlas of the Amazon: 1-153. Smithsonian Books, Washington and London.

HIMSTEDT, W., 1996. Die Blindwühlen. Die neue Brehm-Bücherei 630:1-160.

HOFRICHTER, R., 1998. Systematik der Amphibien. In: R. HOFRICHTER (Ed.): Amphibien. Evolution, Anatomie, Physiologie, Ökologie und Verbreitung, Verhalten, Bedrohung und Gefährdung: 36-63. Natur Buch Verlag, Augsburg.

MACIEL, A. O. \& M. S. HOOGMOED, 2011. Taxonomy and distribution of caecilian amphibians (Gymnophiona) of Brazilian Amazonia, with a key to their identification. Zootaxa 2984: 1-53.

MOLL, D. \& E. O. MOLL, 2004. The ecology, exploitation, and conservation of river turtles: i-x, 1-393. Oxford University Press, Oxford.
NUSSBAUM, R. A. \& M. WILKINSON, 1995. A new genus of lungless tetrapod: a radically divergent caecilian (Amphibia: Gymnophiona). Proceedings of the Royal Society of London. Series B, Biological Sciences 261(1362): 331-335.

POUGH, F. H., R. M. ANDREWS, J. E. CADLE, M. L. CRUMP, A. H. SAVITZKY \& K. D. WELLS, 1998. Herpetology: i-xi, 1-577. Prentice Hall, Upper Sadle River, New Jersey.

TAYLOR, E. H., 1968. The Caecilians of the world: a taxonomic review: 1-845. University of Kansas Press, Lawrence.

VITT, L. J. \& J. P. CALDWELL, 2009. Herpetology. An introductory biology of amphibians and reptiles. Third Edition: i-xiv, 1-697. Elsevier, Amsterdam.

WAKE, M. H. \& M. A. DONNELLY, 2009. A new lungless caecilian (Amphibia: Gymnophiona) from Guyana. Proceedings of the Royal Society of London. Series B, Biological Sciences 277: 915-922.

WELLS, K. D., 2007. The ecology and behavior of amphibians: i-xi, 1-148. The University of Chicago Press, Chicago and London.

WILKINSON, M. \& R. A. NUSSBAUM, 1997. Comparative morphology and evolution of the lungless caecilian Atretochoana eiselti (Taylor) (Amphibia: Gymnophiona: Typhlonectidae). Biological Journal of the Linnean Society 62: 39-109.

WILKINSON, M., A. SEBBEN, E. N. F. SCHWARTZ \& C. A. SCHWARTZ, 1998. The largest lungless tetrapod: report on a second specimen of Atretochoana eiselti (Amphibia: Gymnophiona: Typhlonectidae) from Brazil. Journal of Natural History 32: 617-627.

WILKINSON, M. \& R. A. NUSSBAUM, 1999. Evolutionary relationships of the lungless caecilian Atretochoana eiselti (Amphibia: Gymnophiona: Typhlonectidae). Zoological Journal of the Linnean Society 126: 191-223.

WILKINSON, M. \& R. A. NUSSBAUM, 2006. Caecilian phylogeny and classification. In: J.-M. EXBRAYAT (Ed.): Reproductive biology and phylogeny of Gymnophiona (Caecilians): 39-78. Science Publishers, Enfield (NH), Jersey, Plymouth.

WILKINSON, M., D. SAN MAURO, E. SHERRAT \& D. J. GOWER, 2011. A nine-family classification of caecilians (Amphibia: Gymnophiona). Zootaxa 2874: 41-64.

ZUG, G., L. J. VITT \& J. P. CALDWELL, 2001. Herpetology. An introductory biology of amphibians and reptiles. Second edition: i-xiv, 1-630. Academic Press, San Diego. 